\title{
The Second Annnal Meeting of the Japanese Association of Rehabilitation Medicine
}

\author{
Held at the \\ National Education Centre \\ 3-4 Kasumigaseki, Chiyoda-ku, Tokyo \\ April 11 th, 12 th, ' 65
}

\section{Lectures of members}

\section{Plenary Session}

Chairman : Prof. T. Kobayashi (University of Tokyo)

1) Prosthetic Treatment in Rehabilitation for Palatal Deficieny (2nd Report)......T. Miyazaki, Y. Okuno, T. Tsugi, N. Torii, T. Matsuya and T. Mimura (Osaka University Dental School)

2) Rehabilitation of Rheumatic Heavy Disabled at Ito Hotsprings...... It Ito and Y. Inaba (Ito Hotspring National Hospital and Ito National Recuparation Home)

3) Rehabilitation of Cardiac Patients. Special Reference to the Application of the Telemetering...... T. Kobayashi, Y. Ito, M. Takeuchi, T. Koro, I. Tawara and Y. Taneichi (University of Tokyo)

4) Social, Economical and Psychological Problems in Medical Rehabilitation......S. Takaguchi

(Kagawa Rosai Hospital)

5) Present Status of Disabled Children in Hyogo Prefecture........ Sakata (Nojigikuen, Hyogo) and M. Fujiwara (Kobe Medical College)

\section{Plenary Sessions}

Chairman : Prof. S. Shikano (University of Tokyo)

6) Use of Contact Lens for Injured Eyes....... Fukamichi, K. Shinozuka, Y. Hamada, J. Shoji and Y. Shimada (Kanto Rosai Hopital)

7) The Value of Lowvisionaids for Partially-sighted Children....... Kubota (University of Tokyo)

8) On Rehabilitation Clinic in Ophthalmology......S. Matsui, M. Wakita, (National Rehabilitation Center for Visually Handicapped), A. Nakajima, K. Konyama, N. Shiojima and M. Sakaguchi (Juntendo University Medical School)

9) Some Problems on Rehabilitation for the Blinds Caused by Behcet Syndrome......T. Shimizu, Y. Oshima (University of Tokyo), M. Wakita, S. Matsui (National Rehabilitation Center for Visually Handicapped), K. Konyama, A. Nakajima, (Juntendo University Medical School) and S. Shikano (University of Tokyo)

Plenary Sessions

10) Rehabilitation for Fracture of Senile...... T. Otsuka and Y. Higashikawa (Tamatsukuri Koseinenkin Orthopaedic Hospital)

11) Relative Metabolic Rate in Prosthetic Gait of the Lower Extremity Amputees......S. Sawamura and M. Uno (Kobe Medical College)

12) Experiences of Medical Rehabilitation for the Amputee.....T. Tsuchiya (Yokohama University School of Medicine), Y. Sato, T. Okawa, H. Horii and K. Nakagawa (Kanagawa

Prefectural Rehabilitation Center)

13) Objective Measuremens for Low Back Pain by Occupational Therapy......T. Hara (Kyushu Rosai Hospital and Rehabilitation Center)

14) Application of Various Tasky in Occupational Therapy and the Evaluation of its Effectiveness by an Analysis of the Functional Components of Each Tasks......T. Hanaoka

(Osaka Rehabilitation Center)

\section{Plenary Sessions}

Chairman : Dr. M. Kase (Kanto Hospital)

15) Rehabilitation of Minamata Disease...(The First Report) …... Og. Ogata, H. Tokunaga (Kumamoto University) N. Ohashi, Y. Oniki and M. Ikebe (Minamata City Hospital)

16) Rehabilitation of the Patient with Progressive Muscular Dystrophy........ Nojima. N.

\footnotetext{
* Special Lectures were uppered in No. 2, vol. 2
} 
Shinno, H. Arita and T. Iwake (Tokushima University)

17) Braces for Gait and Scapular Fixation in Progressive Muscular Dystrophy....... Nojima, H. Arita and T. Iwaki (Tokushima University)

18) Rehabilitation for the Sensory Paralysis of Leprosi....... Tachikawa and M. Narita (National Tama Zenseien)

19) Vocational Adjustment of Cerebral Palsied...(Second Report)......T. Sato, Y. Katayama, H. Fujii, Y. Nagayama and S. Iwasaki (Hiroshima Research Group of the Cerebral Palsied)

20) Difficulties in Hip Joint in Cerebral Palsied Children in Relation With a Rehabilitation Programme.....S. Mizuno, K. Ono, I. Kajiura, G. Kuroda, A. Inoue and O. Nojima (Osaka University Medical School)

21) Prognosis and Rehabilitation of Myeloradiculoneuritis $\cdots . . . M$. Kase, J. Ono, N. Yoshimasu, Plenarry Sessions

E. Hiyamuta and K. Sugiura (Kanto Teishin Hospital)

Chairman : Prof. N. Tsuyama (University of Tokyo)

22) Some Observation on the Giant Spikes of Spastic Paralytic Muscle....... Murakoshi and S. Watanabe (Chiba University)

23) An Electromyographic Study on Motor Ataxia....... Nakao, S. Kito and T. Tsubaki (University of Tokyo)

24) Electromyogram in Cerabrovascular Accidents.....K. Shibata, M. Ugaki and J. Moriya (Osaka Rosai Hospital)

\section{Symposia}

\section{Rehabilitation of Cerebrovascular Accidents}

Chairman : Prof. Takashi Sugiyama

25) Psychological Aspects of Rehabilitation, (2) The Intelligence of Hemiplegics...... J. Sonoda, M. Suga, M. Kawano, T. Kanehisa (Kagoshima University) and T. Yoshimuda (Fukuyama Hospital).

26) Osteoporosis in Postapoplectic Hemiplegic Patients...... S. Tei and T. Kubota (Izu Nirayama Spa Hospital)

27) Studies on the Rehabilitation of C. V. A., (3rd Report) : Electrocardiographic Changes of Adult Hemiplegic Patients......H. Hiragami (Tohoku University)

28) Risk Control for the Rehabilitation of Hemiplegics....... Hirakata, K. Fukui and K. Kobayashi (Kakeyu Balneotherapeutic Hospital)

29) Studies on the Rehabilitaiton of C.V.A., (2) The Evaluation of the Function of Paralyzed Uper Limb ….R. Morizono, M. Suga, T. Kanehisa (Kagoshima University) and M. Maeda.

(Miyazaki Spa Hospital)

30) Medical Rehabilitation of the Hemiplegic Patients with Cerebrovascular Disorders ….... Tsuchiya (Tokohama University), Y. Sato, T. Okawa, H. Horii and F. Shoji (Kanagawa Prefectural Rehabilitation Center)

31) Studies on the Physical Training of Postapoplectic Hemiplegic Patients, (2nd Report) The Possibillity of Functional Recovery of the Affected Fingers and Hand.....S. Sato (Sendai National Nospital),

32) Course and Mode of Improvements in the Fundamental Motor Skills in C. V. A......S. Mizuno, K. Ono, I Kajiura and A. Inoue (Osaka University)

33) Functional Improvement of C. V. A., Special Reference with Neurological and Laboratory Findings...... T. Aizawa, Y. Goto and K. Murakami (Keio University)

34) Clinical Study on Application of Oriental Physical Medicine in Rehabilitation, (1) Therapeutic Stimulation of Muscles by Use of Needle Electrode and Pulse Generator ….K. Serizawa, T. Fujita, K. Mori (Tokyo University of Education), Y. Oshima, K. Takahash (University of Tokyo). S. Tei and T. Kubota (Izu Nirayama Spa Hospital)

35) Speech Therapy of Aphasia Introduced by Cerebrovascular Accident and it's Correlation with the Involved Extremities......K. Fukui, K. Kobayashi and Y. Hirakata (Kakeyu BaIneotherapeutic Clinic).

36) Population Study of C. V. A. with Reference to the Rehabilitation (1st Report) In the Kuzumaki Town, Iwate Prefecture..... T. Sugiyama, R. Hanakago, N. Sawaki and M.

\section{Scientific Exhibit}

Kayaba...... (Tohoku University).

1) Ophthalmological Rehabilitation. M. Harada (University of Tokyo) 


\section{Film Presentation}

1) Members of Society on the wheel chair: Impression at the Stoke Mandeville Game in Tokyo....... Kimura (Sendai Rosai Hospital).

2) Out-door Rehabilitation for the Patients of Spinal Cord Injury and Hemiplegia......S. Baba (Mimihara Hospital, Sakai City)

3) The Actual Status of Habilitation and Employment for the Cerebral Plasied in Hiroshima ..... T. Sato (Hiroshima Reserch Group of Cerebral Palsied).

4) Rehabilitation of the Patients with Progressive Muscular Dystrophy....... Nojima, N. Shinno, H. Arita, and T. Iwaki (Tokushima University)

5) Prosthetic Problems of Lower Extremity Amputees in Japan......S. Samamura and M. Uno

(Kobe Medical College)

6) Rehabillitation of C. V. A......S. Mizuno (University of Osaka and Osaka-fu Medical Association)

—御知らせ

1. 日本リハビリテーション医学会事務所の電話番号が10月 1 日より下記の通り変更いたしました

\section{3 局 1151 番 内線 332 番}

2. 学会費の納入は, 医学会事務所宛御送附下さいます様, 御影い致します，く日本リハビリテー ション医学会 東京都文京区雑司ケ谷 東京大学医学部付属病院分院内 振替口座 東京80181番>

3. 現在会員数（昭和 40 年 9 月 20 日）医師 816 名医師以外 28 名 計 844 名

\begin{tabular}{|c|c|c|}
\hline 義 手 足 & $\star$ & 実 用 特 許 \\
\hline コルセット & $\star$ & 先天性股関節脱且 \\
\hline
\end{tabular}

翼森義肢製作所

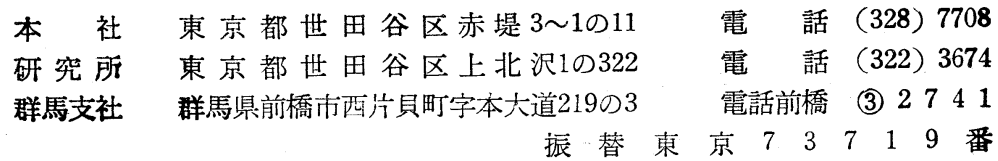




\title{
第 2 回 日本リハビリテーション医学会*
}

\author{
会員講演, シンポジウム, 科学展示, 映画展示 \\ 抄録及び附議・質問・答
}

\section{I. 会員講演抄録及び附議・質問・答}

$[1] \sim[24]$

\section{〔1]顎欠損に対する歯科補緅学的リハビリテーショ} ンについて一第 2 報--

(大阪大学口腔外科) 宮崎 正 辻 忠良 松矢篤三 三村 保

（歯科補綴）奥野善彦 鳥居則成

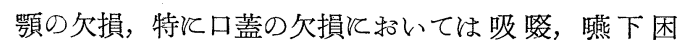
難, 鼻腔分泌物の口腔への漏出, 咀嚼能率の低下, 発語 の不明膫等種々の障害が生じる。特に発語の不明膫は患 者の日常生活飞大きな影響を与え, 心理的影響も大でこ れの回復はリハビリテーションととって重要な問題であ る。今回は後天的な口蓋欠損のため非常な障害を生じた 2 症例飞ついて歯科補経学的飞回復をはかり，このため に作製したスピーチエイドの効果を種々の方法により測 定した結果を報告した。

症例 I は 6 年前右上顎癌の除去手術を弓け治痛後硬軟 口蓋飞 $30 \mathrm{~mm} \times 22 \mathrm{~mm}$ の卵円形欠損を生じ，このため 上記の様な障害を訴えたものである。症例 Iは左側軟口 蓋部の癌腫を除去後 1 年半を経過したもので左側軟口蓋 が後方にむかい扇形飞欠損しているものである。これら 2 名の患者は共管理職飞あるため特に発語の不明膫は 職業上大きな障害となっていた。

これらと適用したスピーチエイドは維持部を歯牙にも とめ Co-Cr 製とし，後方欠損を補填する部分の作製飞 は, 周辺組織を圧迫しない様，かつ十分閉鎖効果をあげ る様印象をとり，これを透明アクリル樹脂製とした。症 例 I 特いては欠損部が大きいためアクリル樹脂の部分 を中空にして重量の軽減をはかった。これらスピーチエ イドの装着によりその障害は非常によく回復されたが， その効果を次のごとく測定した。

\section{発語音節明瞭度試験について}

症例 I では装着前54\%であって発語の約半分しか正常

* 昭和 40 年 4 月 11，12日 於東京虎の門国立教育 会館,なお特別講演は本誌 2 巻 2 号に揭載ずみ。
そ聴取出来なかったものが装着後は93\% \%向上し大きな

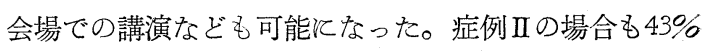
から 75\% V回復した。症例 I, II共破裂音, 磨擦音が鼻 音汇置換されることが多かったが，装着後これがなくな り，会話時患者の声とききなれた者を通訳としていたが これが不要となった。

\section{呼気の流出状態について}

発語時に使用する全呼気量とその時の鼻腔よりの漏出 気量の割合を鼻腔漏出率としてこれをポリグラフで測定 した。正常人が鼻音を除いてほぼ0の值を示すのに対し スピーチエイド装着前は症例 I・IIを通じ84\%〜33\%の 漏出をみたが装着後は47\%～17\%程度に改善された。鼻 音とついては装着前後共正常值とほぼ同様の值を示し た。

\section{発語時に於けるロ腔内圧について}

口蓋欠損により発語時に口腔内圧が高まらないため構 暗障害をあらわすととは当然であるが装着後両症例とも いちじるしく改善された。

○との他の口腔諸機能について

咀嚼能率の測定結果は症例 I 亿括いては歯牙欠損を補 綴したため通常の義歯使用者と同じ程度の值を示した。 症例公飞和いては歯牙欠損がないため咀嚼には関係な い。更にX線映画法により㺞下の量や時間, 燕下時の活 動状態を観察し装着前後に执いて大きな変化を認めたが これの詳細とついては次の機会飞報告したい。

以上の如く客観的に見てもスピーチエイドによる諸機 能の改善が認められたが，患者自身もこれてよって職業 や生活に新らたな元気を取りもどし各及指導的な立場に 立って現在活躍を続けている。スピーチエイドひ装着後 はこれそなれると従ってその機能回復の程度も向上して いるが，以上のデータを患者飞説明し練習飞も明るい希 望をもたせ，各種の障害が原因となって社会生活飞も消

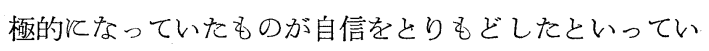
る。従来は手術後放置するが, 単なる義歯の変型の様な 補経物によりその機能回復も不十分であったが，スピー チエイドの装着により機能回後が十分に可能となり, 更 飞社会心理的な障害を改善しリハビリテーションと成功， 
てた症例とついて報告した。

尚装着前後飞和ける発語の変化を録音テープにより再 生した。

質問

（東京大学分院内科）小林太刀夫

音声の明瞭度について称教光下さい。

答

(大阪大学歯学部) 鳥居 則成

発語音節明瞭度試験では無意味音節試験を行なってい る。日本語音67音を均等飞分散した単音節，2 音節，5 音節カードを患者飞読ませ, 聴力正常の熟達した試験員

（S T ） 3名にて聴取し, 後に判定し百分率で表示した ものである。

\section{〔2〕伊東におけるリウマチ起因重度身体障害者のリ} ハビリテーションについて

（国立伊東温泉病院）伊藤久次

（国立伊東重度障害センター）榉葉安雄

国立伊東重度身障センターは, 医学的管理を一つの目 的とした国立伊東保養所として国立伊東温泉病院に併設 せられてから満10年を経，今は長期のリハビリテーショ ン施設としての傾向が大となった。その間の入所者総数 212 名中重度 (身体障害者福祉法一級) のリウマチ起因 身障者は50名（男 7 ，女33）23\%に特よび起因疾患別で は最多数をしめ, 又女子入所者総数69名中の約半数はリ ウマチであって，重度身体障害者対策の中でもリウマチ そ関する部門は比重が殊に大であることを示唆してい る。

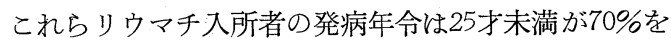
しめ, そのうちでも小学校終了年令までの発病者10名。 そのうち 7 名はリウマチのため未就学であった。結婚後 の発病は11名でうち8 名 (男 2 , 女6) は離婚の憂目を 見ている。発病した時期は大平洋戦争中 15 , 戦後 5 年 13 であって戦時戦後の混乱期の最悪条件飞因果関係がある と思われる。副腎皮質ホルモンが普及した昭和29年以降 の発病者は 4 名のみであるが，果して副腎皮質ホルモン 普及のためかどうか悑速断出来ない。

リウマチのリハビリテーション過程の第 1 は疼痛対策 である。P. T. は鎮痛作用としても有能であるので, 殊 江身障者ほど P.T. を必要とする。50名中 1 名を除き P· T.を受け，これ《反し O. T. は問題であって，50名中 16名は O.T.というょり A. D. L. を一をずの到達目標 としたいわゆる O.T. 飞終っている。O.T. 飞入れた 34 名は, 手芸 10 , 筆耕 2 , ミシン 2 , 機械あみ 16 , ラジ オ組立, 時計修理各 1 などである。強直性脊椎炎の 2 は Standing desk を使用した。
Gadget を入所当時使用したもの10名であるが，退所 時まで使用したものは数名のみであった。

リウマチ患者は心理的飞も問題がある。50名中発熱疼 痛をしばしば訴劣るもの20名で，7名は心理学上問題の ある患者であった。また重症うつ状態のもの3名で，い ずれも本りハビリテーション過程より脱落した。

ADL そついては立上り動作, 移動動作は脊髄損傷, 脳性小览麻痗々同程度飞悪 $く$, 食事動作, 日用器具使用 動作も他の重度障害者より僅かとよい程度であった。リ ハビリテーションルよる各動作の回復の状態は上肢の動 作の機能障害よりも下肢の方が悪く，かつ䄧そいことは 脳卒中の場合とは逆である。逐年回復改善状態を観察す ると 3 年目にはとの速度は頭打ちになってきている。 年以上やっても中には多少改善されるものもあるが，一 般には進歩の見透しは少なくなるし，また中には逆に再 発して悪くなったものもあった。

今日末でのリハビリテーションとよる効果は，全体と しては有効 26 , 不確実 15 , 全くなし9であって, 半数に は効果が見るべきものがないということになる。

退所者28名の退所時転帰は, 目的達成 10 , 〔社会復帰 (就業) 5, 家庭復帰 5]脱落13[家庭飞て保護 8, 病 院入院 5]死亡5である, な杼社会復帰といってももと より軽作業や産業であって，従来の仕事に関連したもの が多く, 常人の域には達し得ない。家庭復帰も自用を他 人の手助けなしに出来る程度である。病院入院はりウマ チの増恶再発 3, 重症反応性亏つ状態 2 , 死亡 5 のうち 4 は明らか、心臟死であった。

すなわち重度少ウマチ起因身体障害者はリハビリテー ション施設中にも再発増悪があり，また常に疼痛を訴え るもの少なからず, 心理的精神病学的にも問題があり,リ ハビリテーション効果も必ずしも上らず，乙かも就職就 業も意のごとくならず，心臟合併症も重篤となる場合も ある等各種の困難性があり，これと他の重度身障者と同 一視しがたい点も少なくないので，リウマチ専門のリ八 ビリテーション施設が必要であるととを痛感する。 （本研究は厚生科学研究費によるものである）

\section{附議 1}

関西医大 森 益太

リウマチの高度身障者の予防または症状飞対し, 何か Surgical aid の面から扔助けする余地がある様飞感ず るととが少なくないが，先生の御高見を得れば幸いであ る。

\section{答}

保存的療法へ症状固定してから入所させるものですか ら，整形外科の方が手をつけてよい場合の方がもしろ多 かったのではないかと思います。施設の性質上とれが出 
来てくいので, 病院の方でやるようにして和ります。こ の間が 1 本巵なるう制度が改まるとよいと思います。

\section{附議 2}

（横浜市大整形外科）土屋 弘吉

括話では患者の大部分けP.T.を受けているが， O. T.を受けている率は少ないようですが，私の考えで は重度リウマチ患者で岗るほど一層 O. T. の余地が多い と思われますので，O．T. 、ついてどういうように考觉 て括られるか招伺いし李。

\section{答}

O.T. は V.T. そ結びつき得るものをここでは述べ， A.D.L. の方に結びつくものをここでは除いてあります。 殊て指の機能障害が甚しい場合には A.D.L.を少しでも よくする方向にしています。

\section{附議 3}

（大阪大学整形外科）水野祥太郎

整形外科側から申しげると，重度の変形や強直をき たすものは，内科的治療の間に肢位についての注意をし ていただくことを拓願いしたい。下肢をまっすぐに，し かも足を直角值くこと，手の母指を対向位飞括くこと の点を守っていただけば，強直をきたした患者も容易に 手術的または非手術的に処理してリハビリテーションが 可能となる。最覀の場合は肘関節をひろく切除して正常 そちかい運動をつくることもでき，股関節を人工骨頭置 換によって歩行に有利にかえることもできる。

\section{附議 4}

(千葉県楼ガ丘育成園) 金子 純雄

いわゆる施設と医療機関に和ける「リハビリテーショ ン」の相違を知って頂きたい。

純粋なる「メディカルリハビリテーション」は施設と 乙ては十分にやれない。施設の入所の条件として症状固 定，身障者福祉法の障害程度によって収容するので慢性 病患者の「メデイカルリハビリテーション」はやりにく いのである。

\section{附議 5}

（東北大学鳴子分院）杉山 尚

私ども内科医からリウマチ患者のリハビリテーション を考えるとき，広い意味のリハビリテーションとして は，当然，薬物によるコントロールということも包含さ れるべきと考えていますが，リウマチのリハビリテーシ ョンというと，どうも従来整形外科的立場からの身体障 害者の手帳すなわら法の面からのみ考学られがらであ る。そこで従来の考光方にこだわらず，リウマチのリハ ビリテーションという広い立場から重度のリウマチとい

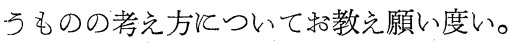

ここで述べる重度とは身体障害者福祉法 1 級のもので あってリハビリテーションの概念も狭義のものです。入 所資格として薬物のコントールを余り受けない程度まで 症状固定したものをいつています。薬物はサリチル酸あ るいはブタゾリジンを短かい期間だけ使用させていま す。ステロイドは使用をしません。

\section{附議 6}

（厚生省衛生院）吉田喜三郎

Finland の Heinola 病院の Dr. Kauko Vainio 重度リウマチの手指の整形手術を行ない，リハビリテー ションに大きな寄与をして扔られることを感銘いたしま したので，阪大整形の方の積極的に協力したいという御 発言に対し，付言させていただきました。

\section{[3] 心疾患患者のリハビリテーション}

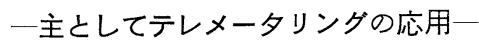

（東京大学分院内科）小林太刀夫 伊藤良雄 竹内馬左也 紅露恒男 俵 穆子 種市良博 心疾患患者の運動能力の判定に, 日常生活の自然の状 態に掠ける観察が可能な点で，テレメータ方式による連 続観察は有用である。

回復期より社会復帰に至る過程に和ける活動能力の評 価と運動量の増し方: 予後, リハビリテーションの成功 そ和よぼす因子の分析を目的として，心筋硬塞 27 例，冠 不全80例，弁膜症37例，計 144 例につき運動能力を判定 し：この中アンケート方式により実生活調査をし得た62 例，又調查時期と同時に再検査し得た13例の成績などよ り得られた知見につき報告する。運動負荷試験の判定基 準は N.Y.H.A.の分類飞，心電図所見：心博数，血圧 などの他覚的所見を加味し，次のごとく分類した。

1) 任意の速度で歩行 5 分および高さ $17 \mathrm{~cm}$ の階段 24 段昇降 5 回を行なっても自覚症沶よび，心電図所見，心 搏数，血圧などの他覚的所見に特記ずべき変化の見られ ないもの。2a）: 全過程で軽度の自覚症を伴うか，他覚 的所見飞軽度の変化を見るもの。2b):階段 1 回以上で 中等度の自覚症を伴うか，他覚的所見に著明な変化を見 るもの。3）歩行5分以内で，強い自覚症を伴うか，他 覚的所見飞著明な変化を来すもの。4）坐位，立位又は 極く短時間の緩除歩行でも著明な上記変化をきたし，ほ とんど歩行不可能なもの。血圧の無線搬送方式はまだ問 題点があるが, カフ圧曲線, $100 \mathrm{mmHg}$ 較正矩形波と, コロトコフ音シグナルの出現, 消失時点より測定する方 式を用いている。

運動負荷による反応様相を軽度変化を含めて疾患別に 検討すると, 弁膜症群では心搏数, 愁訴, ST.T が主に 反応し，冠不全では ST.T と愁訴r血圧の Factor が 
同程度に加わり, 心筋硬塞で蛅 ST.T の反応が一番大 きくき活とんど全例をしめる。心筋硬塞の回復過程の運 動量を設定するには勿論, 臨床症状, 安静時心電図, 生 化学的検査所見などを参考にしているが，この際，自覚 症のみに頼ることは危険であり，われわれは心電眓，心 搏数血圧などの反応を見ながら漸増式飞運動練習を行な わせている。また体酸素消費量と比較的比例するといわ れる心搏数を横軸に S T偏位を縦軸にとって, 卧位, 立 位, 歩行中, 階段昇降中, 臥位直後, 臥位 2 分などの点 を結ぶと，冠不全状態の動きをあらわすloop が画かれ る。すなわち loop の横の延びそ対して縦の延びの多い ものはより冠不全が強い々解され，又 loop が閉じない むのは回復過程が不良で冠予備力が少ない事を現わして いると考えられる。

実生活最大運動量のエネルギー代謝率 (R.M.R) と検 查時最大活動量との相関を見ると R.M.R \pm 0.5 を誤差 範囲とすると $58 \% ， \pm 1.0$ をとると $81 \%$ が一致した。又 安全度をみて許可した運動量と実生活推定活動能力との

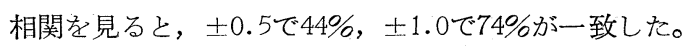
検查と実生活上の運動量との不一致度を検討すると，4 カ月位まではよく一致し， $6 \sim 7$ カ月迄は比較的よく一

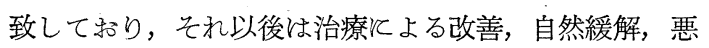
化などの原因で不一致例が生ずる。この事はかかる検查 は半年に 1 度位, 行なった方がよい事を示す。実生活調 查時々一致して再検査した例では，運動量過大のもの に, 改善, 悪化が半々で他のものは, 大部分が運動能力 の改善を示した。乙かし少数例ではあるが調查より推定 した運動能力と思われる労作を実際と行なわせると，推 定值々一致しない例がみられ，乙の事はやはり自覚症の みでなく, 他覚的検查の必要を示唆する。この他リハビ リテーションに参考になる事として，心筋硬塞では適正 な運動量を決め難く. 弁膜症では自覚症, 心搏数が大きく 変化するためか，患者が割合よく自分の運動量を認識し ている。又重症のものは過多のもの多く, 軽症飞過少の ものが多い。経済の良くないものは過多の傾向。C.M.I の $M-R$ 得点上り見ると非神経症群飞過多のもの多く, 神経症群過少のもの多い。仕事対する意欲は，ある ものはないもの、比べ運動量適合するものが多い。今回 の症例飞限って社会復帰状態を見ると, 約半分程度迄の 仕事量飞復帰したものは大略70\%に達した。以上，われ われは心疾患患者のリハビリテーションとあたっては, 患者の自覚症のみならず，他覚的所見を加味した運動能 力の検定が有用である事を示し, 又実生活調查と運動能 力の適合度を見，その間のズレを是正し，又患者の実生 活内容を知る事《より患者の指導《当ってより妥当な線 飞近づき得る事をのべ，よりよいリハビリテーションの
ためには，医師側の態勢の完備と共に，患者との接触の 緊密化が必要であり，又心疾患患者も，よい指導と管理 により, 可成りのものが十分仕事に復帰出来るものであ る事をのべた。

〔4] Medical Rehabilitation における社会的, 経 済的ならびに心理的問題に関する1考察

(香川学災病院理学診療科) 高口真一郎

\section{A) 香川労災病院中の Reh. 対象者の実態}

昭和39年 10 月現在の全入院患者は 221 名で，そのうち Reh. を主として必要とするもの (Reh. 対象者) 67 名であった。すなわち Reh. 対象者は全入院患者の30.4 \%に相当し，そしてその各科別では整形外科 6.3 : 内科 2.2 : 外科1.5であった。しかしながら現在は一般治療を 主としているが，将来恒久的または慢性の障害者となる と推定される者をも合算すると，Reh. の立場からの診 療の必要性の高いものは約40\%にのぼる。

B) 現在 Reh. 中の重度障害者の Need 調査から一 主として心理社会的問題について

Reh. そ括ける Social Worker の役割は(1)として 保健所や他の関係当局との協調による障害者の発見・報 告和よび障害者への Reh. の説明より成る病院前の業 務，(2)病院または Reh. Center 飞括ける業務, (3)退院 後の業務または後指導などが含まれていると云われる。 (1)(3)につてて地域社会に括ける Reh. Service の円滑 化のための綜合計画と関連して極めて重要であるが，こ こでは主として(2)を中心として論ずる。(2)関しては Reh. Team から Social Worker がぬけているならば 患者は一般的個人的な関心が払われなくなり，彼は自 分で心理的舕よび実族的諸問題を解決する緊急の必要飞 迫られるわけであり，また(3)関連した家族や社会への 再適応も問題となってくる。この Reh. そ和訬る心理的 とり扱い《社会的経験不足に対する情報提供ないし説 得から “主として情緒的側面関するとり扱いこまでが 必要とされる。

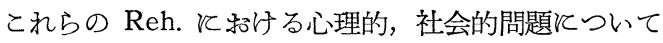
現在 Reh. 中の重度障害者46名 (全 Reh. 対象者67名の ろち恒久的または慢性の障害者であるかまたはとうなる 見込のもの）を対象として調査したところ35名より回答 を得た。それとよると「回復の意欲がある」と肯定して いるものは20名いるが，「退院後の計画が出来ている」も のは僅か3名であり，主として障害者の家族構成，経済 的，社会的条件などを考慮した上での社会の受け入れ体 制の問題が重要であることを示している。るたこれら重 度障害者の心理的指導の Need はかなり高く(34.3\%) さらと障害者にとって最も大切であると云われる「自分 
の障害を合理的化受け容れる」問題については必ずしも 満足すべき状態ではないようである。

そこで次に P.T., O.T.はもちろんのこと，これら心 理社会的 Reh. 面の専門員をも含吉 Reh. Team の強 化と深々関連している経営採算面飞言及する。

C) 当面の労災患者 Reh.をめぐる諸問題一主として 労災病院における一

I) 労災病院は一般大病院上共通な低医療費の活办 に，かなりの比重をしめる Reh. 部門の低コストのため に，2重の経営採算上の困難を背負わされている。すな わち

(1) Reh. 面の比較的少ない一般大病院飞括いても, 低医療費のため追試・研究面への資金の投入が困難な傾 向市る。

(2) との上労災病院は，その Reh. 施設と労災医療の 本義からして労災患者の Reh. を引きうけているが。そ の Reh. 関係の低料金のために大きな赤字財政となって いる。これら労災 Reh. 患者の中には本来身体障害者福 祉法による公費負担で行なわれるべき部分飞相当してい る者がかなりいるとも拘らず，他の患者と同じように採 算をとろうとしている。

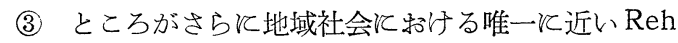
施設であるため，労災保険以外のリハ，コースへ入る患 者（片麻痺など）をも收容せざるを得ないので，それら の比較的低コストをも背負うことになる。

II）近時身体障害をのこす疾患の死亡率が減ずると之 もに, これら Reh.の需要は益々大きくなりつつあるの で，特に採算面や地域社会の問題飞ついて何らかの根本 的な対策が必要であると考光られる。(以上飞関する当 院関係の資料などをスライドとて示した）

追加

\section{社会復帰した脊䯑道損傷患者の調查報告}

（大阪市大整形外科）小谷 勉

脊損の医学的リハビリテーションは現在ある程度, 成 果をあげて和りますが，実際社会復帰した脊損患者の実 態を調查いたしましたので追加させていただきすす。

今回調查の対照になりましたのは，昭和32年以降に， 大阪周辺の 2 つの労㷋病院と市内の 1 の市民病院より退 院しました106名にアンケートを就くり来院させたり訪 問したりして，直接調查し得た 67 名について述べをす。 水野教授が昭和26年よりとりあつか方れた症例㤁含まれ ていませえ。

スライド・尿路感染飞よる発病・排尿の状態・床ずれ - 一般状態・排便・日常生活・職業

一般飞退院時の医学的リハビリテーションの状態は維 持されてはいるが，折角修得した wheelchair が日本
の生活様式汇あ⿱丶万佂，家屋の一部をどうしても改筑する 必要がある。

$$
\text { スライド・その例 }
$$

職業補導のための施設を経由して，正式に職業の補導 をうけたもの残念ながらわずか例㰝ない事実 からも，生活様式から来る条件の不備は将来の問題かと 思われる。

調查した職業のあり方はスライドのごときものであ り，43名が親戚家族などに養なわれている訳であり，こ の点 Vocational Rehabilitation のレベルマ䅂いては 大変不満足であります。

しかし，乙の困難汸ち勝って独立して立派な社会人 として，十二分飞社会復帰をしている数例を調查し得た ことは李ことルよろこばしいことと存じます。

・3名の場合のスライド

最後飞，現在労㷋病院の waiting list 飞は100名以上 の脊損患者をかか党て和ります。最近10名の入院通知を 出したところ，そのうち 7 名が死亡したとの通知接し たほどであります。立派な施設をもっている病院から円 滑な社会復帰をはかるためには, Vocational Rehabilitation でのレベルでの運営が久除していると思われる。

\section{質問}

（東京大学中尾内科）上田敏

障害による2次的な心理的問題の他飞, 外傷性患者に拉 いては「事故を起こし易い」病前性格があり，それが「り」 の過程でトラブルの原因となることが多いと云われてい る。事故の種類の違い（米国では自動車事故，ダイビン グ）もあろうがわが国の外傷性脊損ではこの点どうか。 答

（香川学苂病院理学喰療科）高口真一郎

私自身は調查していないが，リハビリテーションと拉 ける心理的問題は通常動機づけを中心として論ぜられる ものであり，この動機づけについてはリハビリテーショ ン，潜在能力の評価か，その養成かなど諸説あるが，そ の中で外傷前性格を強調する説もかなり有力のようであ る。

\section{〔5]県下肢体不自由児の実態調查一予報一}

（のじぎく園）坂田政泰

（神戸医科大学整形外科）藤原 誠

肢体不自由児の実態把握は種々の難点ぶあり，昭和 29 年の文部省, 昭和34年の厚生省, その他の $2 \sim 3$ 統計を 除いてはみるべきものはない。

厚生省は肢体不自由児の登録管理を発足したが，方法 論, 予算難よりほとえど有名無実に等しい。

これらの点から全国的傾向と一致して, 兵庫県下に掠 
ける肢体不自由児の実態把握は，ほとんど不可能に近く 肢体不自由児対策の重大な障害となっている。

われわれの理想は悉皆調査であるが，その点では可能 性より断念して，種々の整形外科医によるデータを綜合 してよりよき結果を求めんと試み，3 力年計画の約 1/3 を終ったので現況を報告する。

兵庫県の人口は約 420 万で中 18 歳未満は約 120 万，その $0.81 \%$ の約 1 万が肢体不自由と推定されるが，今回はと の約半数を掌握し得た。

疾患別忆見ると, 脳性麻㽻が約半数をしめ関節疾患は 約 $20 \%$ とれれつぎ，保健婦活動乞の他により先天股脱 対策の充実は大い反進歩したとはい方をだ多くの問題を 残す。ポリオも，生ワクチンの普及によるとはいいなが らほぼ同数を示し，約 5\%を占める形態異常も見逃すこ とは出来ない。結核性骨関節疾患, 脳性麻疩及びポリオ を除く麻㾇, 外傷性疾患, 骨疾患はいずれも3\%程度又 はこれ以下となる。

な招, 地域により発見率に大差を有し, 保健所, 福祉 事務所，父母の会の連関の密接な所注ど発見率も高く 又，受療率も高いことは，リハビリテーション専門医を 中心とした，リハビリテーション・チームスよる活動の 重要性を示唆している。

諸先輩の御批判を仰ぎよりよき実態把握の基礎とした い。

\section{質問}

（北海道旭川整肢学院）七戸 幸夫

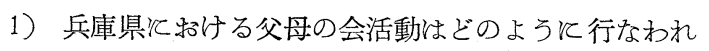
ているか?

2）本調查中，重症心身障害児は特よと何\%と把握され たか?

答

（のじぎく園）坂田 政泰

1) 父母の会活動は, 肢体不自由児の発見と定期的訓練 を行ない得る様に努力を集中している。その結果, 数力 所飞执いて，定期的訓練の場を得た。

2）重度心身障害児の範ちゅうに入る者は10\%弱であ る。

\section{〔6〕外傷眼に対するコンタクトレンズの効用}

（関東学災病院眼科）深道義尚 篠塚清志 浜田陽子 庄司 準 嶋田洋子

眼外傷の中, 薬物次よる角膜腐蝕や角膜の鈍傷, 裂傷

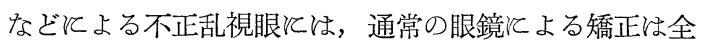
く不可能である。また片眼の外甥性白内障手術後の無水 晶体眼者に扮いても, 高度の不同視のため通常の眼鏡て よる矯正恃無意味である。これらの患者飞対しては, コ
ンタクトレンズの使用により, 著明な視力の増進を認め るのみでなく，片眼無水晶体眼者も両眼の使用が可能に なる。過去 5 年間に和ける経験例飞つき報告する。

\section{〔7〕弱視児に対する弱視レンズの適用}

（東京大学分院眼科） 久保田伸枝

私どもは，前回弱視レンズ（外界や文字を拡大する光 学的補助具) が低視力者のリハビリテーションと非常に 有用であることを述べました。との後実際飞使用し，長 時間の使用にもあまり疲れを感じないなどの良い結果を 得玉した。今回主として小，中学校の盲学校の弱視児に ついて弱視レンズの適応者を調查いたしました。

調査の対称は, 久我山盲学校の弱視児 57 名, 葛飾盲学 校の弱視児48名です。

用いました弱視レンズは次の 4 種類です。

1) 遠用単眼望遠鏡（2 倍の試作品）

2) 近用眼鏡型
i ) バー型レンズ ( 2 重焦点)
ii）アアスフェリックレンズ（非球面特殊レンズ）
iii）広角レンズ（広視野近用眼鏡）

調查の結果は次の通りです。

1)，久我山盲学校

$\begin{array}{lll}\text { 遠用適応者 } & 28 \text { 名 }(49 \%) \\ \text { 近用適応者 } & 17 & (30) \\ \text { 近用不適応者 } & 22 & (39) \\ \text { 近用不用者 } & 18 & (31)\end{array}$

2）葛飾盲学校

$\begin{array}{lll}\text { 遠用適応者 } & 29 \text { 名 }(60 \%) \\ \text { 近用適応者 } & 16 & (33) \\ \text { 近用不適応者 } & 12 & (21) \\ \text { 近用不用者 } & 22 & (46)\end{array}$

以上のうち，適応者を疾患別飞調べると次の上うにな ります。（近用眼鏡型適応者）

$\begin{array}{llll}\text { 小眼球症 } & 12 \text { 名 } & \text { 先天白内障 } & 6 \text { 名 } \\ \text { 白児眼 } & 4 & \text { 先天白内障手術後 } & 3 \\ \text { 強度遠視 } & 2 & \text { 脈絡膜欠損症 } & 2 \\ \text { 全色盲 } & 1 & \text { 視神経萎縮 } & 2 \\ \text { 角膜白斑 } & 1 & \text { 計 } & 33\end{array}$

不適応者の主な理由は，このような拡大鏡を用いずに 教科書の字がよめるというものが40名いました。その他 点字しか知らないので使完ないもの, 精薄を合併してい るもの，まだ病状の固定していないもの，コンタクトレ ンズがよいもの等を除きますと, 真の不適応者 (適応す るレンズがない者) はわずか 9名にすぎません。

そこで視力が0.01から 0.2 迄で教科書の字がよめない 弱視児について適応者を見ますと，65名中33名 (50\%) 
となります。昨年調查いたしました成人の場合は82名中 63名 $(77 \%)$ で弱視児の場合は少し少なくなっていま す。拡大倍率は弱視児は 5 倍前後が多く, 成人では 8 倍 以上の高倍率が必要でした。

最後に後視児に対する弱視レンズの適応については， 小学校低学年では，近用の眼鏡型は使いにくく，字を拡 大すると一字一字沁読めても文章として意味がとれ委 え。そこで弱視レンズは漢字などを挌ぼえるのと部分的 そ使するのがよく，それとは眼鏡型より手持型や卓上型 がよいことがわかりました。

小学校高学年叔よび中学生では，本など持続して読も のとは，眼鏡型が具合よく，黒板を見たり，ノートを見 たりする時には 2 重焦点レンズが適当です。細かい図 表, 辞書などを見るのに不自由している弱視児について は弱視レンズは非常に有用であり, 弱視教育にぜひ役立 たせたいと思います。

\section{附議}

\section{（大阪医科大学眼科）湖崎 克}

1) 現在の弱視レンズは高価なものであるため, 生活困 窮者飞対して，更生医療の対象として補助されるよう， 本学会より当局に㗢きかけていただきたい。

2）小児と成人の弱視レンズの適応率の差は, 文字の認

識，文の読解力の差のためと考㝋る。

3）授業中のレンズの用い方には今後大い、検討の余地 があると思う。

4) 読書以外飞手先きの仕事に用いるととにより，視覚 障害者の新職業開拓に役立つものであるう。

\section{〔8〕眼科リハビリテーションクリニックについて}

（国立東京視力障害センター）松井新二郎 脇田末つ克

（順天堂大学眼科）中島 章 紺山和一 塩島永都子 坂口美邑

昭和39年 2 月国立東京視力障害センターと順天堂大学

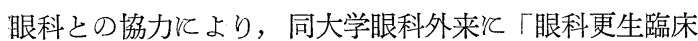
相談所」が設けられた。従来は外来よりセンターに直接 症例を紹介していたが，かかるクリニックが病院の一部 として存在することは患者側信頼感を与兄との後の更 生指導を容易化出来ると考兄られたためである。相談所 は外来患者の中, 視力回復の見込みのない症例次社会復 帰の緒を与えるべく広く一般眼科医からの依頼も受入れ ている。39年度の受入れ総数は70名を越光，われわれの 意図した主旨が実証された。本相談所は眼科診療施設と 厚生施設の間の空間を埋め，両施設本来の機能をたかめ るもので，久しく設立の必要性が痛感されていたものの モデルである。

\section{追加}

(大阪学芸大学・九大小児科講師・大阪市大小坚科講師) 高木俊一郎

1）クリニックセンターに称汗る料金の問題はどうして 特られるか?

2）私性小児科医であるが，九州厚生年金病院飞招い て, 整形医, 心理学医, 治療士，装具士などとチームに よる指導をしてきたが，特定の病院で，特定の人間の犠 牲と和いてなされるのでなく，それらの指導料金が高く 評価され斌ば発展してこないと思う。

本人から高価淿とるという意味ではない。医療保護の 費用を出してもらってもよいが，正式视点数計算とし て，高く評価されるように㗢きかけてもらいたい。これ ほリハビリテーション学会の問題としてのべたわけであ る。

\section{附議}

（順天堂大学眼科）中島 章

1）このようなクリニックがうまくいくか否かはチーム ワークが必要であり, しかす, 経験汇豊九だ指導担当者 そよって初めて成功するものである事をこの一年間クリ ニックを見て感惑した。このクリニックが出来たことに ょって, 再来患者の質飞変化が生じ, 医師の負担が軽減 された点がある。また一方，若い医師の内には，安易な 気持で患者をリハビリテーション外来迴す傾向が生じ やすく，これは大きな問題である。

答

（国立東京視力障害センター）松井新二郎

「リハビリテーション・クリニックそついて」

\section{質問}

相談とついて，費用はどうするか？

答

現在は無料（但しこれはある程度テストケースである こと)

(1) 将来保険料金江組入れる方法もある。

(2) 厚生省あたり飞も積極的林リニック設置方を要 請しこれの費用を考慮してもらうべく検討中。

(3) 各都道府県の更生相談にてクリニックを取扱うこ と。

答

このクリニックルよって，眼科外来の診療能率が上昇 し，それ《よって生ずるプラスを考光，これを病院当局 飞納得せしめる事が大切であり，今の木までも，病院側

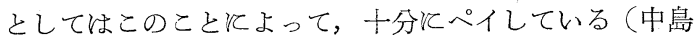
章) 
[9]Behçet 症候群による盲人のリハビリテーショ ンに関する諸問題

（東京大学物療内科）清水 保 山本恵一郎

大島良雄

（国立東京視力障害センター）脇田まつ方 松井新二郎

（順天堂大学眼科）絉山和一 伊藤信義 中島 章

(東京大学眼科) 鹿野信一

Behçet 症候群 (以下B-症候群と略) $\sigma$ 症状発現活粘 膜・皮膚・眼部限局せず，全身的多彩性を示し，から それが反復出没しつつ慢性遷延性経過をたどるのを特異 的とし，これて起因する失明率が大きい。従来中近東地 中海沿岸諸国，ついで欧州に多いとされたが，近年本邦 飞郝汗る患者の発生は世界各国を遙か、凌駕する状態 ある。演者らは本症の本邦に括计る疫学的重要性と, こ れ飞よる失明者の Rehabilitation 飞伴亏特殊な困難性 に対する実態炈き報告し、二，三の問題につき考察を 加光た。

1) B-症候群の疫学的重要性：東大物療内科比招 て臨床経過を follow-up した63症例では，男子飞悪化 傾向がつよく，病勢は初発後 $5 \sim 7$ 年を peak とする。 1957年9月～1965年 4 月の観察例計 145 例（男96例，女 49例) 飞つき発病の年別推移では，本症の発病は1952年 以降漸増傾向を示し，失明率男子33/86例 (38.3\%), 女子7/46例 (15.2\%) となり，観察期間の延びるとつれ 増大する可能性がある。いわゆる Neuro-Behçet 型は計 14症例が観察され，うち4 例死亡。3 剖検例江共通する 所見として脳, 脊髄白質, 視神経㳻在する脱骾性小軟 化巣が特長的であり, 多発硬化症, Neuroemylitis optica Dévic そ類似するが, その発生機序はいまだ明ら かでなく，自己免疫的機構の介在も示唆される（大島， 清水)。眼科領域の統計では，1954 年以降 9 年間の東大 眼科外来患者 117,174 例中ブドウ膜炎例 1,607 例，原因 不明のブドウ膜炎では本症が圧倒的に多く, 全ブドウ膜 炎の $28.3 \%$ 占め, 年年増加傾向にある。李た順天堂大 学眼科の推定では, 本邦の視覚障害者推定数 23.4 万名, うち約 $2.5 \%$ が虹彩炎，ブドウ膜炎によるとし，全国の B一症候群患者推定概数は眼障害末期の者で約 1500 名, 事実はこれを上廻る患者の存在が考兄られる。後天的失 明者 (成人盲) の Rehabilitation-Center である国立 東京視力障害センターの最近 7 年間の集計成績では, 全 センター収容盲人のB 一症候群仙基因するものは1959年 以来激増し，1964 年度は8.4\%の比率を占めるにいたっ た。

2) Rehabilitation 上の諸問題: 患者は失明後も他
の臨床症状の出没するものが多く, 鍼众, massage 等 の実技訓練に耐兄られない者が多い。一方，青壮年期飞 失明する本症 (とく飞男子) では, 社会的, 経済的理由 から，これら盲人の更生指導，職種撰定上飞も困難な問 題が多く, 更生職種と乙て鋮炎, 按摩実技不能の者が多 い。かつ，本症に上る盲人をかかる更生施設飞収容する 飞際し, 慢性全身病としての本症の性格上, その病期の 判定が重要であるとともに，かかる盲人の更生施設に法 これと直結する医療施設の併存する機構であるべきとと が望香れる。近年本症が日本㴔増しつつある点にか九 がみ以上の点をとくに強調したい。

\section{[10]老人骨折の機能回復}

（厚生年金玉造整形外科病院）大塚哲也 東川 裕

老人の定義は難しいが，ここでは便宜上60才以上とす る。

本院に入院の上整形外科機能訓練を行なった患者総数 は2 614例，乙の内老入疾患は84例 (3.2\%) を占め, 更 飞骨折は84例中61例 $(73 \%)$ をしめる。

老人骨折では矢張り, 大腿骨近位端骨折が最も多く, 脊椎骨折，下腿両骨骨折の順となっている。

年令別では65才が最も多い。

性別は男性が女性約の 2 倍をしめる。

原因別では転倒が最も多く, 転落, 打撲の順となって いる。

受傷前後の職業変動は，離職が $23 \% ，$ 転職が $7 \%$ とな っている。

老人骨折では一般骨折患者飞較べて骨癒合汇長期を要 するため，固定期間も延長し，従って入院期間，訓練期 間等も延引する傾向が認められる。るたこの間軟部組織 の萎縮も起こるので, 隣接関節の強い拘縮をきたし易い。 一方老人は機能回復拉よび社会復帰に対する積極的意 欲に欠けて和り，又簡単なととで事故を起こし易いので， 整形外科機能練訓飞当っては以上の点を十分考慮に入れ て，監視を特こたることなく，積極的飞心理治潦を行な うと同時に，受護の気持を持ちながら，無理のない規則 正しい機能訓練を引続き行なう様指導しなければならな い。この事は老人疾患全般のリハビリテーションにも当 てはまるものと思われる。但し合併症のある症例ではそ の取扱いに特に慎重さが望まれる。

これとょり訓練終了時の機能回復状況は一般骨折患者 の機能回復に較へ，その成績はやや劣るとしても，これ 飞可成り近い程度迄回復させる事が可能である。

ただし問題となるのは矢張り一般骨折と同様下肢骨骨 折の場合，膝関節拘縮を残し易い点であろう。 
疼痛に関するアンケートは, 病棟訓練を行なった37例 飞ついて行ない，その77\%のの回答を得た。

疼痛内容では両般的にみて「しびれ」感が最も多い が，一般骨折患者の疼痛内容に較べてその訴光の比率が 少ない。

疼痛発現の状況は, 寒冷時疼痛が最も多く疲労時疼痛 がこれに次ぐ。

すなわち寒冷或いは疲労飞よる局所の血行障害は疼痛 の原因の重要な因子となるが，老人では一般患者飞較べ て，その比率が高い傾向が筧われる。

有痛時処置としては温泉が最も多く, マッサージ, 安 静, 温湿布の順でこれらとより局所の筋緊張を柔らげ, 神経の興奮性を低下させ，局所の血行をよくする方法が とられている事が分ると同時に，温泉等の温熱効果が心 理的, 精神的安静を与ている点も見逃せない。

また一部「はり」「食」等も行なわれているのも老人 の特殊性とも云えよう。

日常生活動作についてのアンケートは病棟訓練 23 例 （内国民年金法による障害判定を行なったもの16例）で， 訓練室訓練 6 例である。これらはいずれも下肢稆よび体 幹骨折である。

この内で問題となるのは下肢骨折で，本人の主な訴え は歩行或いは正坐障害である。

国民年金法飞よる日常生活動作障害の判定によると， 正坐或いはあぐらをかく事が障害されているものが多 く, これは日本人にとって大切な, 畳の上の生活飞重大 な障害を与えていることを示すもので，下肢骨折治療中 飞随伴発生する所の㯟関節拘縮は, 一般骨折患者の場合 之同様老人骨折飞於いても多くの問題を残している。

機能訓練に当っては各症例の生活様式に応じて, 洋式 或いは和式の訓練の使い分けも大切であろう。

質問

（東京大学中尾内科）上田敏

脳卒中後遺症患者で骨折を合併した例があったか？

追加

浴風園剖検例606例の統計で6.3\% V大腿骨頸部骨折が あり，その $1 / 3$ 強が片麻痺患者であった。脳卒中後歩行 可能になった群のみについてみると $11 \%$ の多くが大腿骨 頸部骨折を起こしている。脳卒中の合併症としての骨折 防止の重要性を強調したい。

答

（厚生年金玉造整形外科病院）東川裕

私共の症例梳 Hirnerweichung は含まれて挌りま せん。

答

（厚生年金玉造整形外科病院）東川裕
老人骨折患者は入院時上り直ちに機能訓鍊（症状に差 支觉ない限り自動運動を主体とした）を行ない，同時に 呼吸運動調整，平衡機能保持等を行なう。また固定期間 中より心理治療を含めた訓鍊汇り全身の機能低下を極 力防止している。これにより現在のところ肺炎その他の 重篤な合併症をきたした倒を経験していない。

\section{[11]下肢切断者の義足歩行時エネルギー消費率 \\ (Relative Metabolic Rate ; R.M.R) の検討}

(神戸医大整形外科) 主任 : 柏木大治教授

（県立身障者更生指導所）沢村誠志 宇野衛男

下肢切断者が義足装着訓練を受けた後に得る歩行能力 の社会的実用性について，リハビリテーション・プログ

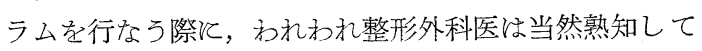
招か齐ばならぬ問題である。いう迄もなく，下肢切断者 の歩行の目的は, 外観, 歩容共江秀れ, 装着感が快適と 共歩行疲労が少ない事が重要である。今回, わ れわれ儀足装用時の疲労の一面を, エネルギ一消費率

(以下 R.M.R. と略) を中心検討, 若干の知見を得た のは報告する。

A) 症例 男 9 例, 女 5 例の14例 (延19例) 両大腿切断 2 例, 一側大腿切断 9 例, 一側下腿切断 3 例, 健常者 1 例を含み義足装着後最短 3 力月, 最長 2 年 3 力月間機能 訓練を行ない，ほぼ満足すべき状態で検査した。尚処方 した義足江両大腿切断例江吸着式, 一側大腿切断例《吸 着式 7 例で全て㯟遊動とし，常用大腿義足 2 例で，その 1 例恀膝遊動式, 他 1 例は膝固定式がある。下腿切断例 は全て膝蓋腱荷重義足である。

歩道は板張り一週30mの長方形で, $100 \mathrm{~m}$ 歩行せしめ, 歩速を 75〜88 歩/分とした。階段抙段 2 段して左折, 降階 2 段で， 2 分間操り返させた。1 段の高さ $24 \mathrm{~cm}$, 奥行 $24 \mathrm{~cm}$ である。

R. M.R. 測定はダグラス囊法に従った。測定日は毎年

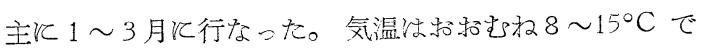
あった。基礎代謝値は片山の統計を引用, 非切断と想定 した体重を逆算, 高比良の式より体表面積を求め, 年 令, 性を加味して算定したもの学使用した。

B) 成績 (第 1 表)

C) 考察 (1)断端性状の不良例, 断端長の短い例, 関節 拘縮のある例，訓練期間の短い例，身長の低、例等飞杼 いては明らか、 R.M.R. が高く, 以上の問題点のない 例でも，階段昇降検査で结健常者比比べ著しく高い值を とる。今後の義足設計上改良すべき点と考光られる。(2) 昇階段昇降江和ける大腿切断例之下腿切断例との差は, 降パターンの差 (大腿切断例で法左右交互飞前に進めな い例が多い)によると思われる。下腿切断の児島例の身 
第 1 表

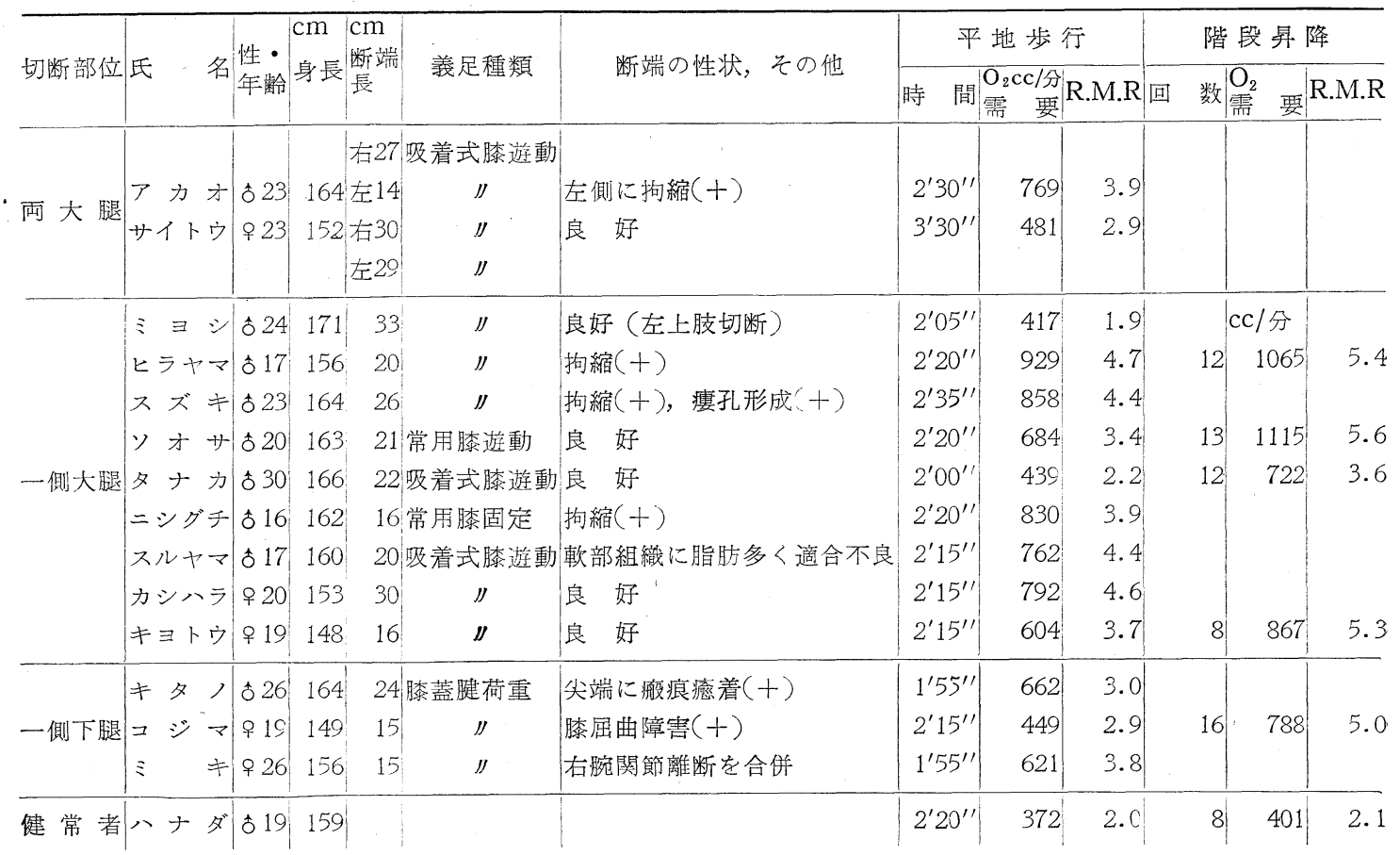

長の低い事，括よび時間内昇降回数の多い事を見れば， その差は明らかである。尚, 田中例《身長の高い事が大 きく影響している。(3)両大腿切断例では，断端の長い斉 藤例が赤尾例より R.M.R. の低い值を得ている。経済 的な歩行に断端長が重要な因子である事を示してい る。(4)一側大腿切断例飞和いて, 吸着義足と常用義足の 比較を身長和よび訓練期間の略同じで，断端に問題のな い田中, 宗佐, 西口例に新いて行なった。吸着式（田中 例）汢平地步行，階段昇降共に明らか、低い值を示して いる。吸着性により義足を保持する為, ピストン運動の ない事起因すると考光られる。常用㯟遊動式（宗佐 例）と常用滕固定式（西口例）との差は，吸着式との差 程大ではないが，明らか膝遊動式の方が低い。これは 義足遊脚時の蹴り出しの機序を考光れば，その時の体重 心移動の大きさから理解し得る。(5)義足の歩行能力に捛 よぼす影響（特にとの適合状態, Alignment) も無視出 来ぬ程大である。その実例をスライドで示したが紙面の 制限のためここでは略す。

D) 結語 (1)平地歩行では, 良断端, 良適合, 良Alignment の例圢健常人々の差は少なく, 特飞下腿切断例は 差が少ない。然し, 階段昇降に和いては，差は著明に増 加する。(2)一側大腿切断例義足は, 吸着式, 常用膝遊動 式，常用滕固定式の順飞 R. M. R. は少なかった。(3)R. M.R. の比較検討には, 断端の性状, 長さ, 筋力, 関節
運動範囲和よび適合，Alignment 等に十分注意を払う 必要がある。

\section{質問}

（九州学災病院リハビリテーションセンター）

原武郎

切断者の義肢使用によるエネルギー消費率は断端の長 さに加えて義肢の種類並びに支持方法, 膝, 足部の機構 も非常に大なる因子と考える。

\section{附議}

（東京大学整形外科）津山直一 Chopart 離断で内反尖足発生は不可抗力的で腱移行 で筋アンバランス妨止の必要性を強調されるのは同感。

\section{答}

\section{(神戸医科大学整形外科) 宇野 衛男}

1）常用大腿義足装用者は 2 名で，1例は膝接手遊動, 腰バンド付 (股接手は無), 他 1 例低，滕接手固定，腰 バンド付 (股接手無)，大腿吸着義足は全例共，滕接手 遊動である。常用義足の種類が少ないとの御発言ですが 現在兵庫県下では，以上の 3 種類がほとんどで，他の処 方のものを検査する機会飞惠まれなかった。

2）結語にも述べた通り，われわれの実験からは，義足 処方飞よる優劣決定は断端状態が解決されてから検討す べきものと考える。 


\section{〔12〕切断者の医学的リハビリテーションの経験}

(横浜市立大学 整形外科)（神奈川県立身体 障害者更生指 導所) 佐藤育徳 大川焗雄 堀井秀和 中川一彦

昭和 38 年 2 月開設以来，約 2 年を経過したが，その間 の入所者総数は 176 名に達し心。

疾患別に分けた時，脳卒中による片麻痺に次いで，切 断者は両下肢麻痺者と並えで，当指導所飞执ける三大疾 患の一つであった。症例は34名上少ないが，肢体不自由 者のリハビリテーションにしめる割合は多い。

年令，性別では，男性か女性の10倍に達し，30才台の 者が最多をしめた。

原因別では，外傷性のものが大部分で，疾病性のもの は少ない。特飞交通事故が最多であるが，労災事故结， 半数が上肢切断をうけている。

部位別では，下肢切断が上肢より多いが，特滥著な 事心両下肢切断が1/3の多き化達した。

入所前の状況に関しては, 当指導所の特殊性を入所径 路に求めた。理想的な病院径由型は8例と少なく, 家庭 径由型20例をしめている。

治療医学とリハビリテーション医学との間の時間的断 層を明確に示している。そのため, 当指導所の対象者 は，陳旧性の後期リハビリテーションをうけもつことと なる。

入所迄の経過期内は 1 力月以内 新鮮例は $6 \%$ み で，大部分が 6 力月以上という長期にわたるものであ る。

入所時の状態をみると, 過半数の者が, 断端不良, 筋 力低下，関節拘縮という二次的障害を併発，更飞変形が 加わり，リハビリテーションを困難にしている。特に注 目すべき合併症として，他肢の骨折を合併したものが 8 \%に達し, 骨瘾合遅延を示した。以上から後期リハビリ テージョンの目的が，義肢装着前訓練にあり，有害な二 次障害の除去である。

特に両下肢切断群急，殆んど 1 年以上の陳旧性のた め, 合併症の発生が高いため，積極的な観血手術を施行 した。尖端潰瘍, 尖足変形に対し尖端形成術を行ない, 関節拘縮に対し腱切り術を行なったが，後者は余り良果 を得られなかった。

尖端部の早期萎縮安定のため, J. May の方法を用 い, Augular turn に変えている.

訓練の状態関して，下肢切断者に対する義肢装着訓 練として, 歩行要素が body の平衡の回復, 消失々い う周期的な bipedal Movementと分析した。そのため balance の習得を最大の目標とし, 徹底的に体重の左 右, 前後移動という初歩的段階を行なつている。特飞問
題となったのは，切断肢の hip hiking 股関節屈伸時の バランス保持, Knee flexion 後方バランス回復であり, 更に両下肢切断者では，広用訓練として，急傾斜面の降

り，階段の昇降，後退歩行が困難であると感じた。

入所期間に関しては，残存機能が最終の目標に到達す るまで十分な訓練期間を設けた。そのためアメリカ，ド イツで報告されている標準的訓練期間に比し，相当遅趧 を認めている。

特飞両下肢切断は，20週以上飞達する。退所後の社会 環境から実用的として有杖歩行をすすめた。

退所後の就職状況では，元職復帰は 5 例にすぎず，大 多数が転職をした。特に両大腿切断の 2 例は授産施設に 入所している。特に問題となるのは地域社会の切断者に 対する受忛入れ方で身体的能力以下の線に和ちつくもの があったことである。

2 年間という短期内の成績から，指導所の特殊性は， 現在後期リハビリテーションを対称としている。そのた め関節拘縮, 尖端不良, 変形という有害な二次的障害を 合併し，訓練の最大の目標が，義肢装着前訓練に和かれ 万。

しかしすでに発生したリハビリテーション阻害因子に 対する除去は，非常に困難である。

治療医学と社会復帰医学との間の险路を如何にすくな くするかは，今後の大きな課題であり，地域社会との密 接な関連性を保ち，早期リハビリテーションの原則に戻 るため努力している。一日も早く, 社会復帰への途が, 速か、行なわれることが, 必要と痛感した。

質問

(神戸医科大学整形外科) 沢村 誠志

1) 大腿切断者の股関節の屈曲拘縮の機能訓練による矯 正は，頙固で矯正を行ない難いようと感じている。この 点についてどの様におやりになっておられるか？

2）股関節の屈曲拘縮に対する義足のアラインメントの とり方につき和教光願いたい。

答

（神奈川県立身障更生指導所）佐藤 育徳 1) 大部分が陳旧性のものであるので，不良肢位（拘縮 変形）を発生，これに対し観血手術を行なったが，結果 は余りよくない，そのため義肢はこれに適した処方にし た。これが訓練期間の遅れた理由にもなる。

2) 屈曲拘縮に対し保在的療法を行なっても, 余り改善 されない。

附議

（九州労災病院りハビリテーションセンター）

原武郎

股関節の屈曲拘縮の矯正には通常 $6 \sim 8$ 週間必要とす 
る。

また治療でさない屈曲拘縮の患者飞対する義肢のソケ ットは initial flexion を増加させてやるとよい。 答

（神奈川県立身障更生指導所），佐藤 育徳 1）当指導所で，切断後に挍ける変形飞対しサイム切断 を行なったもので，ショパール間節離断は全例 4 名上 も，内反尖足変形をきたしており，腱移行術を行なった 例冲認めなかった。

\section{[13]評価手段としての作業療法}

一第 1 報 腰痛テストー

(九州学災病院りハビリテーションセンター)

原 武郎

リハビリテーション医学の診断, あるいは評価方法と しては, 通常の診断学の他飞, 筋カテスト, A. D. L. テ ス卜等に加えて Disability そのものを機能的に評価す る必要がある。また，この Disability の機能的な評価 はリハビリテーションの治療効果, 並びに予後としての prevocational な面で甚だ重要である。しかしながら運
動機能というものは，そもそも患者が自発的努力を行な った結果表われるものであり，その評価汇客観性を持た せる事はしばしば困離な場合がある。これは特に疼痛等 の自覚症が表立つ疾患に申されることである。その良い 例としていわゆる腰痛症があるが,骨，関節等飞明らかな 所見もなく, 李た, 神経学的港異を認めずにただ単 飞患者の主訴のみ飞終わる場合も少なくない。また，そ の他のこれそ類似の腰痛を主訴とする疾患も多くは運動 機能障害を伴うが，その症状は，患者自身の意欲，心理 的な要素《被われて物り, 症状の客観的な把握恀困離な ものとなっている事がいわれる。これは演者が取扱って いる労災患者のリハビリテーションで痛切感じる事で あり, かつ, 補償上一つの大きな問題を提起するものと 申される。そこで演者はリハビリテーション医学の有力 な一手段である作業療法プログラムをとの評価の補償手 段として用いている。すなわち，O. T.のApproach は Functional な面と加えて同時飞 Psychological な 面を有している。つまり O. T. は患者に自発的な完結,

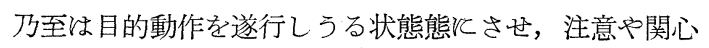
を他に向けさせながら身体症状や機能の面を観察し, あ

(実例)

患者氏名 平進腰痛症テストプロフィール

\begin{tabular}{|c|c|c|c|c|c|c|c|c|c|}
\hline \multicolumn{3}{|c|}{$\begin{array}{l}\text { 検査年月日 } \\
\text { 検 查内容 }\end{array}$} & 39年 6月 8 日 & 39年 7 & 7 月 22 日 & 39年 8 & 8 月12日 & \multicolumn{2}{|c|}{ 39年 8 月 10日 } \\
\hline A & $\begin{array}{l}\text { Sustained trun } \\
\text { fl }\end{array}$ & & 1 分 10 秒 & 1 & - 20 & 1 & - 43 & 3 & - 07 \\
\hline B & Repetitive lift & & 4 回/分 & & 12 & & 14 & & 17 \\
\hline C & F. T. Distance & & $42 \mathrm{~cm}$ & & 36 & & 30 & & 20 \\
\hline D & Rotation and & 右 & 分不能秒 & 1 & - 12 & & 57 & & 42 \\
\hline$D^{\prime}$ & lateral flexion & 左 & 分不能秒 & 1 & - 9 & & 60 & & 42 \\
\hline E & $\begin{array}{l}\text { Hloor lever Pos } \\
\text { ing with Supp }\end{array}$ & & 分 0 秒 & & 16 & & 27 & & 35 \\
\hline F & Maximum pull & & $6.5 \mathrm{~kg}$ & & 17 & & 19.5 & & 20.5 \\
\hline G & Maximum lift & & $45 \mathrm{~kg}$ & & 50 & & 60 & & 60 \\
\hline
\end{tabular}

䛦断 :

第 12 胸椎

第 2 腰椎圧迫骨折兼

第 $2,3,4$ 右腰椎横突起骨折

備考:

検查 1 回目一赤 (一)

$2 \boldsymbol{J}$ 一緑 $(\cdots \cdots)$

3 , 一青 $(-\cdot \cdot \cdot-)$

4 少一黒 $($ 一)

検查療法師：

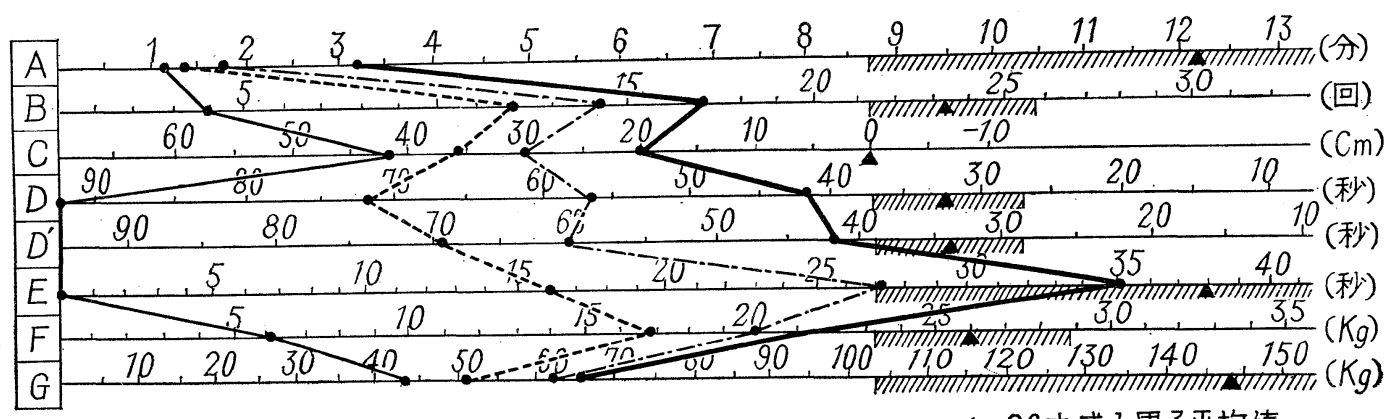

- 26才成人男子平均值 
るいは新たに潜えだ症状を activeに引き出す事や，量 的な綜合評価が比較的容易となる。今回は腰痛を多角的 プロフィールとして評価するのと O.T.プログラムが甚 だ役立つ事を御紹介し諸賢の御批判を仰ぎたい。

テストの方法は A) Sustained trunk flexion これ は固定された Bar $(65 \mathrm{~cm})$ を越えて上体を前屈させ， 床から $42.5 \mathrm{~cm}$ の高さと初かれた一定の広さの盤を前屈 位姿勢を変えることなく移動しながら塗装作業を続けさ せる。乙の前屈姿勢つ耐容時間を分と秒で記録する。B） Repetitive Lift. 患者飞 $45 \mathrm{~kg}$ の重量箱を両手で把持 させ，床から腰つ高さまで持ち上げ，更に床に戻し，直 立位をとらせる。この一連動作を1分間くり返えし，回 数を記録する。C）指と足先との距離を可動範囲で記 録。D) Rotation and lateral flexion; 高い台, 低い 台を一定の間隔で扮き，1 個 $2 \mathrm{~kg}$ のレンガを三段に 40 個 1 列炕して積み重水，高い台より，低い台とレンガを移 す際稫幹の旋逻と屈曲が十分行なわれる様にして右手で 20個, 続いて左手で20個を移動させ，移動化要した時間 を分と秒とで記録する。E) Floor lever positioning with Support, 患者飞軀幹と大腿の角をほぼ $90^{\circ}$ 飞保 たせ滕とクッションを当て，前方にひざまづいた体位を とらせ, 踵は床から $17.5 \mathrm{~cm} の$ 高さのBar で支えて体 位のバランスをとらせる。患者飞は両手を支持に使用さ れぬ様, 床上の箱にペーパークリップを選り分けさせる が，この姿勢がくずれた時をもって持続時間を分，秒で 記録する。 F) 背筋力計とよる maximum lift， G) ホイストを使用した maximum pull。このGの姿勢で Latismus dorsi Abdominal muscle とのバランス作 用が kg で記録される。

以上の 8 種目を平均 26 歳の健康男子15名に行なわせた データーを信頼度 $95 \%$ で母平均の統計学的範囲の推定值 を選えで表の如く配列し（表略）斜線を施こした。この 上下の配列は演者の行なった腰痛症26例の退院時の測定 值平均の小さい順に配例したものである。以上の 8 種目 のテストで得られて記録を色別けの線で結ぶと一目瞭然 そその経過並びに健康值との相違が比較出来てはなはだ 便利である。骨变化のあるもの 44 名, 無いもの12名に ついて現在迄約 200 回のテストを行なったが，両者に特 有なプロフィールパターンを作り得なかった。しかし， E) Floor lever positioning with Support で骨に変 化の無い腰痛症と, あるものと飞一般的飞比較的差異が 大きく見られる傾向にあり，結論をだすにはいたらなか ったが，更に症例を重礼てプロフィールによる分類を検 討したい。

以上，作業療法を腰痛症のテストに用いてその症状を 定量的に表現する試みを行ない，ある程度，客観的で敏
感にその経過を観察するのに便利である事老知り，腰痛 症济する一つの機能的な評価を行う手段である事が分 ったので報告した。

\section{質問}

\section{(東北大学整形外科) 飯野 三郎}

諸障害を客観的に evaluate する手段としてはなはだ 有効かつ合理的な方法として敬意を表する。ただやや心 配なのはこれらの test のある種のもので test のため 飞本来のかくされた器質的変化を増悪する場合がないか ということで，たとえば $4 \mathrm{~kg}$ のものを立位から床上に 下らし，又上げるというような動作は，腰痛とよくある concealed disc 等を顕在性飞増悪せしめる運動と考光 られるが，そのような懸念はないか。

答

（九州学災病院リハビリテーションセンター） 原武郎

多くの腰痛症は急性発症後約 6 力月後であり 1 例の軽 い筋性疼痛増覀をみたが理学療法で軽快した。このテス トルよるリスクは先づないものと考える。

\section{[14]職能療法における多種作業課題の適用の治療的 評価}

(大阪府立身体障害者更生指導所) 花岡俊行 職能療法飞括いて，一人の肢体不自由者に多数の作業 課題を適用することは，治療を要する身体部位の使用の 頻度を高め, また固有の運動パタンを様々な作業条件に 適応させることができる点で価值が高い。さらとこれら の作業課題を身体機能の向上を目的とした治療順位行あ らかじめ編成しておくことは, 職能療法を通じて得られ 機能の改善の効果を判定する上飞有益な手掛りとなる。 この様な観点から職能療法を評価するためと，先づ作業 課題の “achievement” の結果江焦点を置き,動作分析を 基礎として多種作業課題適用の臨床的意義を考察した。

最近 4年間（1961～1964）飞職能療法を弓けた脳神経 疾患江起因する症例名の治療経過を查定し, 適用課題の 種類と指示順位，乞れ飞要した訓練期間から課題 achievement の成果を判定した。対象者が職能療法を実施し た期間は平均 11 力月。一人の症例の訓練時間は 1 週平均 12時間とみなされた。

当指導所の職能療法室で定めた作業種目の治療的な系 列化の分類に基づき，79課題を整理，それぞれと分類記 号を附した。対象例用いた作業は40種目で，一八平均 8 種目が適用され，手芸・木工の利用率が高かった。作 業課題の適用順位は第 1 - 2 回, 中間期と最終回に方け て系統図を作った。初回で組ひも系列作業と板金打出し 作業が多く，坐位での上肢の細かい機能の訓練が導入種 
目と乙て利用し易いことが示された。最終回では木工作 業による四肢の協同的な機能と社会的に必要度の高い描 写運動の練習《重点が㫆かれた。作業の適用期間の長い ものは， achievement の困難なるのとみなされ，手順 の理解，運動範囲筋コントロール，姿勢などの問題があ った。しかし，作業の難易度のいかんにかかわらず，課 題 achievement が成功している事実は，その作業を構 成さる動作要素の一部が, 機能改善, 代償動作, レイア ウトの工夫，道具の改良，要素省略などとよって置き換 えられているととが推則された。この事実を確認するた めに，あらかじめ課題作業の動作を分析しておくことが 必要である。40種目の課題注対して，姿勢のとり方，動 作を行なう主要目的比基づんた Therblig 分類とその 目的を果すための運動パタンの分類で直接測定法により 要素分析を行なった。上肢運動化影響される下肢支持バ ランスや歩行に要する基本運動パタンが主に姿勢の分類 から，一方上肢動作関する28種の基本要素とそれら の複合によって編成される8種の作業過程のパタンが Therblig そ Kinesiology からそれぞれ職能療法で役 立つ機能動作として抽出された。課題 achievement の 治療的効果を，これらの要素の成功率から評価し，特沉 有益であった課題 8 種目を選んで，SMITH の“Organi. zed Motion Pattern” 飞投影すると，多種作業課題を 系統的に適用することが生産的な人間への進路を開き， これらの作業課題が運動性の習熟に役立ち, 職能療法を すすめる上飞重要な道標となることが証明された。

\section{[15] 水俣病の Rehabilitation 一第 1 報—}

（熊本大学整形外科）主任：玉井達二教授 緒方 甫 徳永温正

（熊本県水俣市立病院）大橋 登 鬼木泰博

\section{I. 緒 言}

昭和 28 年飞最初の水俣病患者が発生以来，早 12 年を経 過した。一方灻の発生は本態究明の結果, 昭和35年末に 終息をつげたが，今尚71名の患者が後遺症に苦しんでい る。幸い本年 3 月に充実せる Rehabilitation Center の落成を見たが，我々は本年度からの本格的 Reh. 亿着 手する前飞，水俣市立病院内の施設を利用乙て，昨年 1 月以降10カ月にわたり, 選択的な機能回復訓練を試み, 若干の知見を得たので報告する。

\section{Reh. の対象}

入院中の水俣病 14 名, 胎児性水俣病 7 名, 計 21 名

\section{III. 症状の内容および分類}

運動失調と精神障害を主徵とし，それ《視野狭窄，言 語障害, 聴力障害を伴つて和り, その程度により, 重症, 中等症, 軽症飞分類した。胎児性水俣病は C. P 飞類似
して特り，中等症，軽症は歩行可能で，重症者には殆え ど寝たきりの者もある。

\section{IV. 訓練方法}

1) 水俣病汶対して

a)Frenkel の Exercise, b) 歩行訓練（直線歩行，曲 線歩行，負荷歩行，砂囊を片手に下げての歩行，招上び 水の大ったコップと盈を乗せての歩行）Ｃ）A. D. L 手指 訓練（食事動作，衣服動作，玉差し動作，畫字訓練）d， その他（ラジオ体操，繩とび，球技）

2) 胎児性水俣病飞対して

Sophie. Levitt 女史の C. P 訓練法を採用し，歩行 可能児で出上記の訓練法を併用。

\section{V. 訓練成績評価基準}

健康人の可能範囲を各訓練項目について Excellent とし，程度に応じて次の様に6段階に分類し，それぞれ そ点数をつけ，その綜合点を算して，全体的な機能回数 状況を検討した。Excellent ( 5 点), Good (4点), Fair ( 3 点), Poor ( 2 点), $\operatorname{Bad}(1$ 点), Zero 0 点。

\section{VI. 訓練成績評価項目}

(1)各種の歩行に対しては10mを歩くに要する時間とそ の歩行姿勢て評価し(2起立可能時間で片脚位の開眼, 閉 眼起立を採点乙 (3)前腕の回外回内反復運動を30秒間の回 数で評価し，(4)玉差し動作，ピンセットや八シによる

「つまみ動作」スプーンルよる「すくい動作」を3C秒間 そ行ない得る個数で評価した。

\section{VII. 訓練成績及び考察}

水俣病では 1 月から 3 月迄は，各症例共急激な効果を 現わしているが，重症になる程緩慢になっている。逆に 4 月以降は軽症になる程横ばい状態を示している。この 事は水俣病では訓練初期から急激洨効果を現わして来る が，中等症や軽症では数カ月である限界達する事を暗 示している。軽症例は殆えど健康人に近くまで回復し， 中等症例では大体との70\%程度で限界を示す様である。 重症例は緩慢ではあるが横ばい状態を示さず，訓練次第 で A.D.L が可能な領域と近ずける目標を与えている。 胎児性水俣病は僅かと効果を認めるだけで C. P 同様根 気強い訓練の必要を感じさせる。以上の成績から，今後 のReh. 飞大いなる期待が持てるが，とりわけ，中等症 扣よび軽症が全患者の63\%をしめている事から，半数近 くが，健康人に近い状態で社会復帰可能か，それに近い 状態にて，家庭生活が送机る様になるのではないかと期 待される。

\section{VIII. 結 び}

一部の患者飞対する今回の試験的機能回復訓練の 結 果, 水俣病の今後の Reh. 亿明るい材料を提示し, 半数 近くの社会復帰への可能性を暗示した。 
質問

（北海道立旭川整肢学院）七戸 幸夫

1) 入院拒否28名いるが，その理由は経済的の理由か? あるいは生活上の問題があるのか?

2）水俣病患児济する教育の体制ねどうなっている か?

答

（熊本大学整形外科）徳永 温正

\section{1) 入院拒否の理由}

入院拒否者名のうち，半数近くが軽症にて，現在すで 飞社会復帰している。あとは胎児性水俣病で，母親が手 離すことが出来ない例と老齢で寝たままの状態を続けて いるものである。又人院費用は，全員，生活保護和よび 市負担にて，なかなわれている。

答

(熊本大学整形外科) 徳永 温正

特殊学級江通学可能児では, 病院から, バスで通学さ セている。病院内には現在のところ教育施設はない。

答 座長の質問 (各症状別の治療状況)

（熊本大学整形外科）徳永 温正

精神障害, 聴力障害, 視野狭窄, 言語障害等も大体運 動機能の程度と比例している。又運動機能の中で, 個々 の運動機能は省略して, 全般的な機能回復状況を検討し た。

附儀

（水俣市立病院）大橋 登

リハビリテーションの保険点数を新設するため, 学会 としても運動を起して貪いたい。

答

（東京大学物療内科）大島 良雄

リハビリテーションと関する保険点数改正の要望はま ことにごもっともと考光る。私もこの改正がなくしては リハビリテーションを発達させることは困難と考えてい る。本学会でも保険阙する委員会が形成されて特り, 音た関連学会である日本温泉気候物理医学会でも物理療 法関する点数改正が強く要望されているので，たがい 淕力して目的達成したい。

[16] 進行性筋ジストロフィーのリハビリテーション （德島大学整形外科学教室）野島元雄 新野 徳 有田寺男 岩城 孝 山木博司 亀谷 洋 三好史郎

進行性筋ジストロフィーのリハビリテーションマ関し ては, われわれは，既火日本整形外科学会総会ならびに 李学会江招いて，その病勢の自然進展を助長すると考兄 られる最も重要な因子は，筋の廃用，変形であるととを
明らかとし，リハビリテーションの必要性について報告 する処があった。筋ジストロフィーに招いては現在尚, 筋の栄養障害の進展を直接阻止し得る医学的処置は殆え ど皆無とひとしく，その病変の進展は宿命的なものとさ れている。しかし，笳は筋としての機能を果さなけれ ば，当然の結果として廃用性萎縮に陥る，このことは本 症の宿命的な病変の進展を更莇長することになる，従 って，この因子，廃用，変形を阻止し，筋本来の使命を 活用し，以て生活機能を可及的長期斿たり保持せしぬ ることにとそ筋ジストロフィーに対するリハビリテーシ ョンの意義が存在するものと考光る。

われわれは，以上の筋ジストロフィーと対するリハビ リテーションの理念にもとづき，特に起立歩行能力を失 ったものと対し，適当な補装具を装着世しめ，その能力 を再び獲得せしめること成功し，これ飞重点を赫いて 経験と工夫を重初てきた。その一部は既敒第 1 回の本学

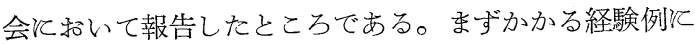
ついて，その経過並びととの後の経験例について，経過

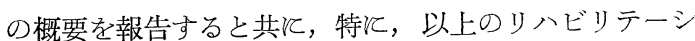
ョンの実際が病勢に与える影響関して，エネルギー代 謝，疲労の面から検討を加兄た。

そず上述の症例の経過の概要については, 補装具在着 用せしめ，歩行能力を獲得後，2 年以上を経過せるもの を中心として筋力, 血清酵素活性值, 尿中クレアチン， クレアチニン, 体重の推移を示し, 特に 1 例は以上の推 移から，病勢がやや進展する傾向を示したが，これ汇は 本症の宿命的な因子の関与が推定される事実を明らか沉 した。

な招，筋力が著明飞減弱し，変形が高度飞して殆ん どリハビリテーションの余地がないと考学られた 2 症 例飞対し，補装具飞より起立能力を獲得せしめ得たとの ベ、かかる極端な症例飞招いてもリハビリテーションの 可能性が存在することを明らか反し，かく対処すること こそ精神面汽える好影響と相俟って病勢の進展を遷延 せしめる手段ではないかと考光た次第である。

上述，リハビリテーションの実際が病勢に与兄る影響 そついては, エネルギー代謝, 疲労度の面から検索し, 問歇的且つ効果的な訓練は決して疲労をきたさず，直接 病勢を進展せしめる因子で蛙いと考兄られる事実を明 らかにした。しかし, 運動量の決定飞当っては, 筋力, 生化学的検索結果, 体重及び疲労度の推移を綜合的飞考 慮して決定すべきであると述べた。

\section{[17] 進行性筋ジストロフィーに対する補装具 一バネ付下肢装具並びに肩胛骨固定装具につい て}


（徳島大学整形外科）野島元雄，藀森宏一 有田寿男 岩城 孝 三好史郎

進行性筋ジストロフィーのリハビリテーションに対す る私共の理念, 技よびその方法飞ついては, 野島が明ら かにした通りである。上述リハビリテーションを実施す るに当って, 能力が減弱し, 変形が高度となった場合飞 は, 当然, 補装具を必要亡する場合が少なくない。私共 は, 起立歩行能力を失ったものに, その能力を獲得せし めるため,「バネ付膝関節装具」を考案し, 満足すべき結 果を得ていることを報告した。その後, 本症にみられる 特異な変形: 腰椎前彎, 翼状肩胛の矯正関して, 筋動 力学的研究並びそその矯正装具について報告した。

\section{1. 翼状肩胛について}

この変形は, 程度が強くなるとつれ, 上肢挙上能力は 減少し，生活動作に障害をきたす。この翼状肩胛をレ線 学的飞検索すると, 肩胛骨は対照飞招いて, 上肢外転举 上之伴い外転, 外旋するが, 軽症型に括いては, 逆に内 転内旋する傾向を示し，更に重症型に扔いては，上腕の 外転挙上飞伴い, 肩甲骨は強く内転, 内旋乃至は下垂す るために上腕骨頭は髀臼下縁に，とりのこされる様相を 呈する。すなわち翼状肩胛に和いては，その程度が高度 となるに伴い，かかる支点の形成が阻害され，上肢外転 挙上時, 上腕骨頭が髀臼下縁にとりのこされる様になる 之考えられる。又肩胜帯筋の徒手筋力テスト結果は, 翼 状肩胛が高度となるそつれ, 各筋力は減少し, 特飞前鋸 筋の減弱が著しく, 重症型に招いては殆んど消失し, レ 線学的検索より明らかにし得た, 上肢外転挙上時の上腕 骨頭の髀臼飞対する支点形成の阻害とは, 肩胛帯筋, 特 飞前鋸笳の筋減弱が大きな役割を演ずることを明らかと した。更に 6 チァンネル同時誘導筋電図を用いた検索結 果も，この事害をよく示した。そこで，力学的解析を加 党ると, 肩㫓骨外転, 外旋筋の減弱が著明な場合飞は. その筋の不足を補う必要のある事が明らかとなった。以 上の理論的根拠飞もとづき: 肩胛骨固定装具を考案し た。この装具出, 左右の肩胛骨の内縁飞適合する, 肩胛 骨圧定装置があり，この両装置の間とバネを挿入したも ので，バネの力により，上肢外転挙上時，肩胛骨を外方 飞圧排し，かつこれを外転，外旋せしめるよう作製した ものである。その装用結果は, 重症型でも, 上肢挙上障 害がよく改善された。

\section{2. 姿勢の異常 すなわち著明な腰椎前彎について} 本変形は, Duchenne 型, ときには Fash 型とも 見られ，この変形火より長時間の起立，歩行には疲労を 訴光，下肢筋力減弱と相俟って，歩行は著しく困難とな る。筋力テストの結果より, 病勢の進展飞伴い, 特汇股 伸展筋の減弱が著明となることを明らかにした。又立位
時綜合重心点を通る垂線を求めると，対照に比し，病勢 が進展するにしたがい，立位時綜合重心は更に後方に移 動していることが分った。更に，立位時の抗重力筋を筋 電図学的飞検索すると, 腰椎前彎が著明となると伴い, 繁筋の活動が活発となる事が分った。以上の事実により 腰椎前彎算筋筋力の減弱が役割を演ずる事実を明ら かにした。またこの力学的解析により，かかる腰椎前彎 を矯正するには，減弱せる肢伸展筋力の補強を必要とす ることをも明らかとし，かかる腰椎前彎を矯正するため の考案せる補装具沉ついて報告した。すなわらそれは， 腰部と大腿との間に弱筋の走行に一致するようアームを 介して，バネを橋渡し，そのバネの力により，緊筋筋力 不足を補ったところ，かなり腰椎前彎の矯正を図ること が出来た。

以上筋ジストロフィーに和ける，特異な変形，卞なる ち, 翼状肩胛, 腰椎前彎飞関して, 筋動力学的観点加

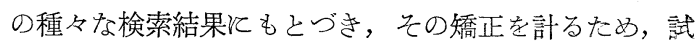
作せる補装具沉いて報告して。

\section{質問}

（東京，開業）山本 理平

1）手術ギプス固定等の強力な医療を含む長期入院中， 体力の低下している筋ジストロフィ一患者の併発病ある いは事故等の状沉は如何 ?

2）本疾患の進行的性質を考光，かかる強力な機能再建 療法を施し，一応の成績をあげえた患者についても，長 期の成績は如何 ?

3）このようなメジカルリハビリテーションの適用は人 道的あるいは個人的に怕当然のことであるが，社会的施 策として，不治進行性とされる本症のリハビリテーショ ンをとりあげることを，現段階に祘いても，既に適当で あると認められるか。

\section{[16・17]の質問}

1) Kranke $の$ 全身的状態

2) 生命飞詨する Prognose の問題

3）社会的に見て Rehab の対象とすることの可否 （德島大学整形外科）野島元雄・他

1）全身的状態が極端に悪いものは，当然除外している が，私共が現在迄汉扱った症例飞和いても，多少全身 状態が悪いと考光られる症例飞括いても起立（補装具装 用の上）せしめると却って好転したものもある。この可 能性の限界々更飞症例を重祇て検討したい。

2) 残念ながら私共はをだ，歩行能力獲得（補装具飞よ り）後 2 年半のものが最長観察例であり, から封照をも たない。更に十分検討を重礼て改めて報告を重ねる。

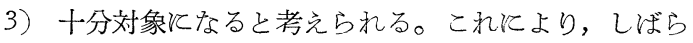
く私共の本症に対するリハビリテーションの理念が当を 
得たものではないかと考光られるに到った段階であり， 更に検索を重放たい。

\section{[16 17$]$ 附儀}

（大阪大学整形外科）水野祥太郎

徳島大のこの方面への寄与はとくにこれが整形外科の もっとも伝統的な方法論を駆使し，乙かもその可能性の 限界点まできわめようとして招られる点で, 私は同じく 整形外科属するものとして敬意を隹らうとともにプラ イドをも感じる。しかし，可能性の限界までつっこむた らには多少のゆき過ざの感をあた劣をのあることも事 実であり，重症身心障害児対策の一部として，本学会の しかるべき専門委員会に执いて採りあげて検討さるべき 段階にきていると思う。

\section{[18]らいの知覚麻痺よリハビリテーション}

[国立療養所多摩全生園(東京)]

\section{立川昇成田 稔}

手や足のある動作が度をこえて強制されると，場合に よってはいろろいな傷害を招くとこにもなるが，そうな るまでに快当然意識的に迴避されるはずである。しかし らいのようと知覚麻痺があると，半ば無意識的な傷害を 招く場合もあり得る。こうしたことを䂆方するために， 条件反射的な注意力を喚起し，また日用器具類の改善や 装具の工夫をすることが，らいと和けみメディカルリ八 ビリテーションの原則として，強くとなえられている。

私達はこの原則に対して，何ら異議をもつものではな いが，てとえ表在知覚が広範飞麻痺していても，深部感 覚はかなり残存している事実を知って，この点も原則の 中で考慮されね棯らないことを述べた。ただ変形が強 くなると，深部感覚もまた障害の程度を強めるが，これ は深部感覚が並行して侵されるというより, 変形のため に知覚されにくい状態にあると理解したい。

ともかく知覚の麻痺した不自由な手足を，より不自由 にさせる傷害から守るためには，まず可能な範囲で変形 を矯正して正しい動作の形を会得させ，次残存する何 らかの感覚を意識させるとともに，傷害防止の注意をう ながすことが，知覚麻痺飞䅦ける傷害予防の大綱と言え よう。

\section{[19] C.P の職業適応について 一第 2 報一}

\section{（広島脳性麻痺研究グループ，広島若草園）}

佐藤俊之 藤井 浩 岩崎貞徳

（同，広島身障者更生指導所）片山義弘

脳性麻痺者の就労については，との障害の多様性と社 会的受容の囲難性によって，必ずしも容易なものでない ことは周知の事実である。しかし，その実態については
いまだ詳細な報告がなされていない。そこで，われわれ は，1964年10月 1 日現在和忛る満15歳以上のいわゆる 生産年齢期の脳性麻盘者について，全県一斉調査を行な った。その結果をまとめたので発表する。

\section{1）分布状況}

第1表 障害程度別生活状況

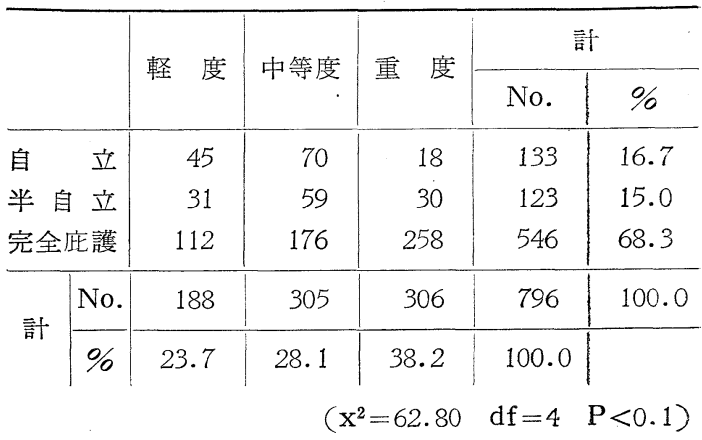

(1) 総数は 799 名で男 480 名，女 319 名であり，原の 男女比は，約 $3: 2$ である。

(2) 高年齢は74歳で，男女共に 1 名ずつである。

(3) 大体，10年を周期として（特に男子の場合）脳性 麻痺人口の著明な減少が招こって和り，60歳をすぎると 激減する。

\section{2）生活状況}

(1) これら 799 名の生活状況は，第 1 表『示すと括り であり，完全庇護を受けている者が68.3\%である。

(2) 性別にみると,

\begin{tabular}{|c|c|c|}
\hline 男子自立者 & 116名 (24.1\% & 群内比） \\
\hline 女子自立者 & 17名（5.3\% & / \\
\hline 男子完全庇護 & 284名 (59.2\% & J \\
\hline 女子完全庇護 & 262名 (82.1\% & 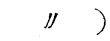 \\
\hline
\end{tabular}

である。

(3) 完全庇護下にある546名のうち，

a）日常生活の完全な介護を受けている者は，190 名 (23.8\%) である。

b) これらの保護者は， 親 405名 $(74.1 \%)$

兄弟 69名 (12.6\%) であり， 施設による収容保護结 16名 (2\%)

である。

\section{3) 就労状況}

(1) 就労者数は，253名であり，うら，120名は半自立 の状態である。

(2)これを性別にみると，

$$
\begin{aligned}
& \text { 男 } 196 \text { 名 }(40.8 \%) \\
& \text { 女 } 57 \text { 名 }(17.8 \%) \text { である。 }
\end{aligned}
$$


第 2 表 障害程度別，職業水準別就学者数

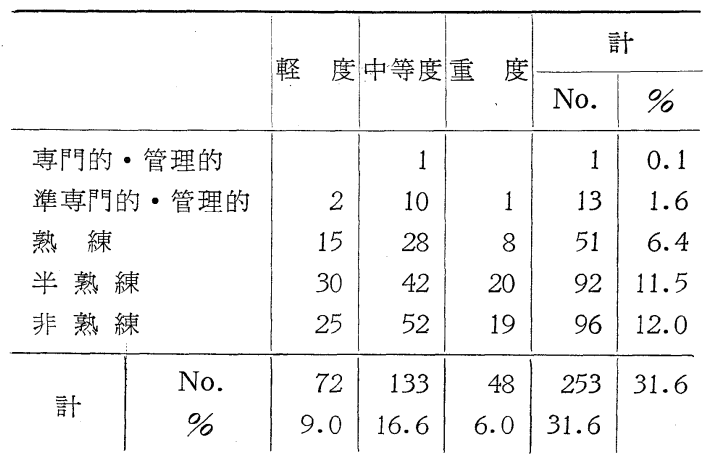

(3) 障害部位別では

四肢麻痺 $14.2 \%$ (各部位別群内比)

両上肢麻瘏 $20.2 \%$ ( J )

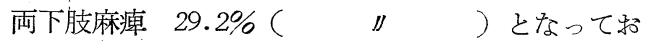

り，これらは，他のものに比して就労率は非常に低か。 た。

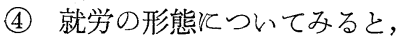

自営 22名 $(28.5 \%)$

被雇用 126名 (49.8\%)

家業 46名 (18.2\%)

その他 9名 ( $3.5 \%$ )

である。

(5)雇用されている126名（全体の15.8\%) は78.6\% が，中小企業及び個人経営事業所務めていて，大企業 て務めている者は 1 名である。

4) 就労および結婚状況

(1) 不就学者は $1 / 3$ 以上飞のぼり, 重度障害者が大多 数をしめている。

(2) 高等学校以上の教育を受けた者は，6.4\% (51名) である。

(3) 646名 (80.9\%) は結婚していない。

(4) 既婚者は，男100名 (12.5\%) 女 32 名 $(4.0 \%)$ で

特に男の場合，既婚者の94\%は就労している。 追加

職業適応の条件について

（若葉園）佐藤 俊之

一般に障害者, 特に脳性麻痺者の就職は極めて困難, かつ不安定である。これを可能にし安定させるためには 一体どのような条件が必要か。私はこれについて次図の よう侾えてみた。

即ち真の職業的安定というものはこれら諸条件或は要 因のすべてが，互いに平衡を保らながら持続する場合に はじめて成立する。

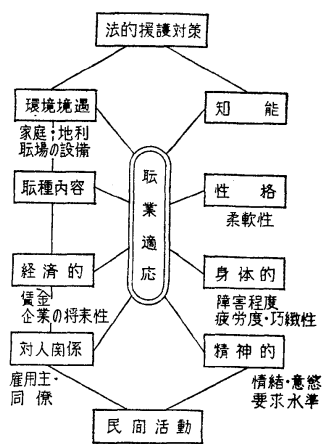

リハビリテーションの最終ゴールが職業自立にある以 上，夫々專門家のチームアプローチが絶対必要であるこ とはいうまでもないが，これと同時に，社会的経済的諸 条件がこれに伴わない限り目標の達成は期し難い。特に 社会的協力態勢の強化を望む。

\section{質問}

（東京医大整形外科）野崎 寛三

1）重度とは手帳の何級を含ませたのか？

2）重度身障者の自立しているものがかなりある様に見 受汁たが，その内容を伺いたい。

\section{質問}

（神奈川県身障更生指導所）大川 嗣雄

1）御報告の中で病型による就労状態に特別な傾向はな かったか？

2）就労期間については特に短い間に転職する傾向はみ られなかったか？

答 (1) 重度の程度

(2)「自立」の内容

岩崎 真徳

1）障害程度は，身体障害者手帳等級別には，重度 1 2 級, 中等度 $3 \sim 4$ 級, 軽度 5 級以下とした。

2）重度障害の自立の具体的個々例については，現在資 料が手許にないが，収入面から 1 万〜 1 万 5,000 円以上 のものを自立としている。

答

(1) 病型不よる特異性

(2) 就労の期間, 転職の状態

佐藤 俊之

1) 症状別には hemiplegie \& paraplegie よりも, athetose の方が就労困難である。

2） C. P. の就労継続期間は，比較的短く，転職ケ一ス が大さい。そのために職業適応の条件について，われわ れは吟味を行っている。

3）障害程度については，われわれ研究グループでは， 
特㵄業適応のための概念規定を行い, 身体的, 精神的 な各面から，軽度，中等度，重度飞分けている。

今回は，身体的な分類を主とした。

〔20]脳性マヒ児のリハビリテーションにおける股関 節の問題

（大阪大学整形外科）水野祥太郎 小野啓郎

梶浦一郎 黒田剛生 井上明生

（大阪整肢学院）野島 治

阪大整形外科 C.P. クリニック，拈よび，大阪整肢学

院の C.P. 児計305例中, 調查しえた133例须て報告 した。

骨頭の側方転位・亜脱臼・脱臼が，症直型ではその26 \%に，不随意運動型では15\%に認めた。

日蓋の異常，とくに目蓋形成不全はかなり高率にみら

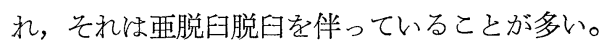

頸体角はほぼ正常範囲であるが，前捻角過大を示す症 例が多く，正常児と異って年長児飞和いても減少傾向が 少ない。

体重負荷による影響を調べたが，C. P. 児では，体重 負荷群洫いても，前捻角がわずかしか減少しない，

痓直性片マヒと括いて，前捻角は健側の方が低值を示 g。

C. P. 巟の股関節は内転・屈曲・内旋位をとりがちで ある。内転位 - 外転位 - 屈曲位 - 伸展位飞招ける内外旋 運動の範囲を検査したが，屈曲位と和ける外旋運動の範 囲よりも，伸展位をとった場合飞，外旋運動範囲が $30^{\circ}$ 以上も減少するものが $62 \%$ ひるられ。対照として正 常児を検查したが，このような現象はみとめられなか。 た。

以上のような事実から，C. P. 児の緊張の強い腸腰筋 が，股関節内旋钾き，骨頭が寛骨臼の後壁飞圧迫され て, 前捻角の減少が阻害されるのではないかという仮説 飞導かれた。

また，C. P. 览の股関節異常が左側に多く，男女別発 生率が女子飞高い事実は，興味ある問題である。

\section{附議}

（横浜市大整形外科）土屋 弘吉

われわれは同様の研究を今回の日整総会飞抬いて神奈 川県立ゆうかり園つ名で発表したが，この研究は股関節 の Pneumoarthrography そよる検討を主としたもの で，先天股脱ではクレブスが内翻しているが，C. P. 股 脱の場合は内翻したものが少し，割合飞変化が少い，こ のこから逆汇ある程度 congenital か spastic か判別 出来るのではないか，その相違の原因は脱臼する時期が 早いか遅いか、よるものではある委いか等と述べた。一
言追加する。

[21]脊髓根神経炎の予後とりハビリテーション （関東透信病院内科）加瀬正夫 小野順一 吉益啺夫 冷车田英三 杉浦啓太郎

近年脊髄根神経炎患者増加の傾向があり, 我々は昭和 28年より39年末までの患者の予后を調查した。この間の 患者の発生は84名で，このうち Myclitis 11名 Necrotic myclitis 3 例, Neuromyclitis optica 4 例, Poliomyclitis ant acuta 4 例, Myeloradiculonenritis 31 例, Polyradiculoneuritis 21例, Polyneuritis 10例で ある，このうち腹部症状を伴うものは33年より30例経験 している。

男女比は29：55 すなわち，1：19である。Myeloradiculoneuritis 140 才以上の女性火多く, Polyradiculoneuritis は30才台の男女飞多く, Polyneuritis は女 性江多い。

予后，短期の予后を Necrotic myelitis を除いて， Paraplegie 呈し, 横断性知覚障害, 屎尿閉示した 20 症を対象沉すると，自力歩行可能となるすでの平均日 数41日, 知覚障害の改善を示すをでが平均 71 日, 自然排 便がみられるまでの期間は36日である。発病時の予后は 膀胱直腸障害, 運動障害, 知覚障害の順㳊善がみらて て行 $<0$

発病 3 力月以上経過したものを長期予后対象者とし,

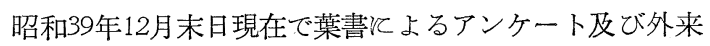
診察により断面調查を行った。84名のうら調查し得たも の58名, 全体の69\%である。調查者58名のうち運動障害 を示したもの51名。このうち活淕全治扰よび軽快がそれ ぞれ39\%，不変11名22\%である。Necrotic myelitis の 患者 2 名以発病後 4 年飞近いが依然 Paraplegie であ る，その他 Myelitis, Polyneuritis 飞予后不良のもの が多い。

知覚障害の長期予后はほぼ全治 $21 \%$, 軽快 $48 \%$, 不変 30\%である。

膀胱直腸障害の予后は運動障害の予后よりややよい。 即ち長期予后も発病時予后々同じく膀胱直腸障害, 運動 障害, 知覚障害の順予后が良好である。

Steroid 使用と予后との関係を調べてみると, 運動障 害で発病より1 カ月以内に Steroid を使用したもの で怯注全治56\%，軽快31\%，不変13\%であり，1力月 以上経過したものではほぼ全治12\%，軽快76\%である。 知覚障害ではカ 1 月以内に Steroid 使用した例では 不変は $13 \%$ と少く, 発病より 1 力月以上経過してから投 与した例では不変50\%と著しく高い。

脳脊䯣液と運動障害の予后との間には明確な相関はみ られない。 
再発沙少く明確な再発上考光られるものは84例中 1 例 に過ぎない，乙かし増悪がしばしばみられた。3年経過 を追った Polyradiculoneuritic の 1 例では第 1 年度 21 回，第 2 年度: 6 回，第 3 年度 9 回神経痛発作を起し，同 時知賞障害の増悪, 歩行障害の悪化が一時的にみられ た。

リハビリテーション、脊䯣根神経炎の予后は Necrotic myelitis を除いて擅好であるから，リハビリテーシ ョンを行うとあたって，患者の不安を除く椂配慮すべき である。最後に機能訓練を行った $2 ， 3$ の例を示した。

附議

（東比大学鳴子分院内科）花籠 良一

われわ秃は非特異性脊髄炎のリ八成績炕関して第 6 回 日本神経学会で報告した。演者の成績と共通する多くの 点を有するが36例の病例を有し，うち29例に下浰若しく は腹部病状を呈したものでこれらは下痢をたは腹部病状 を有しないものに比して予后が良好で経過の上で共通性 を認める。36例の全でが知覚異常を残している。2例の みが運動障害を残していないがこれらは小学生, 中学生 で若い年代である。職場復帰した例でも歩行障害を有し ているもの多く，結局完全治㾍は少ないとい兄る。リハ 実施飞当り注意を有することは余り強力に理学療法, 機 能回復訓練を行うと疲労し易しいので自然回復の経過と 良く見合せて緩除飞行うべきと思っている。

質問

$$
\begin{aligned}
& \text { (水俣市病院内科・水俣リハゼリテーション } \\
& \text { センター） 三隅博 }
\end{aligned}
$$

1) Radiculoneuritis での parästhesie をリハビリテ ーションではどうするか，parästhesie のみの人を対象 の立場よりリハビリテーションの対象としてどうする か。

2）その他知覚障害の評価をリハビリテーションの立場 よりどうするか。

以上を怙教光願いたい。

答 parästhesis 飞対するリハビリテーション

冷车田英三

運動障害の予后は良好であり, 知覚障害のうち Hypästherie の予后も一般飞良好である，乙かし Parästhesie の予后は不良で, 発病後10年か経過しているもので も Parästhesie を訴えいる，このParästhesie そ対 てて種々薬剤を投与してみたが，全て無効である。 追加

（名古屋学第一内科）祖父江逸郎

dysesthesia の発生機序については種々の要因が考兄 られるが，血管性要因や自律神経機能の関与も一つの要 素であるので，対策としてこの面からの考虑も必要であ
ろう。

深部覚障害が合併する運動障害の機能回復にい合併の ない場合より予後が悪いように思われる。

附議

(東京大学整形外科) 津山 直一

知覚検査出くわしくやり出せばきりがないが一応我々 怯 standardize するため反, 表在知覚火は Frey 毛

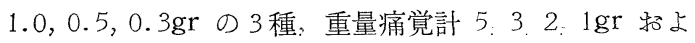
び Area propria の 2 点識別值を用ひ知覚異常範囲のプ ロットルはとがらせたルーレットを鈍麻域よりころがせ 正常感覚になり初める部を記す。

鈍麻, 脱失域が知覚線維の変性型か否かの判定には急 性現象としては Dermohmmetry, (発汗試験と等価), ヒスタミン三重反応のごとき軸索反試射験が参考飞な る。

\section{〔22〕痓性麻㾇筋にみられた High Amplitude Voltage について}

(千葉大学三輸内科) 村越康一 渡辺誠介

私達は脳血管障害 (脳栓塞症 11 例, 脳出血 2 例, 脳動 脈硬化症 4 例) 飞基づく hemiplegia, hemiparese の 患者飞和いて，随意運動時飞 High Amplitude NMU Valtage が健側，患側，にほぼ同様に出現することを みた，(三角筋，上腕二頭筋，上腕三頭筋，総指伸筋， 内側広筋, 前脛骨筋, 腓腹筋飞.括いて 103 筋中 41 筋飞認 めた）その Pattern そは Unit 減少，低振巾の中飞出 現するものと, Unit 振巾には何ら常のない中と出現す るものと二つがある。この二つの型の出現も麻痺側，健 側で大した差はない。又脳栓塞症に主としてみられたの であるが，誘発筋電図的飞検討すると $\mathrm{H}$ 波と $\mathrm{M}$ 波の分離 が不良である。 $\mathrm{H}$ 波、 $\mathrm{M}$ 波の分離良好群の二群飞招ける High Amplitude 出現の様相は今後の検討飞まつ。こ の High Amplitude は老年性の生理的 変化, neurogenic の起元も考慮すべきであるが，春柱前柱細胞にお よぼす, supra segemental の single oscillation, 並 びそ支配比の増大の機構が考兄られないであらうか。

血管性変化が広範飞物よぶと考えるならば，神経機能 が両側性に影響が及んでもよいのではなからうか。

hemiplegia の患者の High Amplitude 出現の機序 の解明は興味ある問題で筋電図学の中枢神経筋系疾患へ の応用の拡大と考克る。

\section{質問}

(千葉大学整形外科) 近藤 正治

1) Giants Spike 飞一定の Pattern が見られるか否 か, 又 Amplitude $\sqrt{ }$ Fluctuation 又心 undulation か見られるか否か？ 


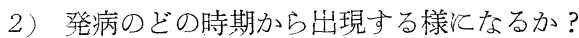

答

村越 康一

1）grouping の傾向を示すものが確か反見られます。 振巾の動摇もあると思い末すが，Histogramm を求め て検討して赫りませんので正確なことはやってありませ 几。

2）発病どれ位から表われるがは一寸分りません。 附議

（東京大学整形）津山 直一

1) Giant Spike が High Amplitude NMU Voltage

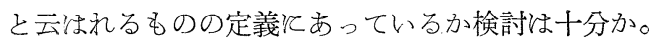

2) suprasegmental $飞$ Causey 理論の応用は endneurium, neurilemma がないだけに可能性は大いに考 へられるが，組識学的検討が望をる。

3）誘発筋電図一H波一から motor cell pool の興奮 準位をうかがう方法はH波が敏感すぎて臨床的所見での 異常の有無とは一致しないことがあるのが欠点で。もう 少しこれを克服する方法の開拓が望まれる。

\section{[23]運動失調症の筋電図学的研究}

（東京大学中尾内科）中尾喜久 鬼頭昭三 （東京大学脳研）椿 忠雄

演者らは16例の春髄小脳失調症について，その筋電図 学的分析を試みる目的で，単一 MMU の放電間隔を検 討し，臨床症状との関係を観察した。被検筋としては上 腕 2 頭筋，腓腸筋，ヒラメ筋を兄らび，下腿筋について は立位と卧位の両体位で検査を行った。その結果，1) 放電間隔図の異常は上肢よりも下肢で著明である。2) Slow Undulation は約半数例でこれをみとめたのに対 し, Irregular Fluctuation は全例で, 臨床的後嗦症 状の明らかでない例ともみられる。3）下腿筋の放電間 隔図の異常が臥位よも立位で著明な例では non-equillibratory co-ordination の障害が少なくむしろ平衝障 害がつよいのと対し，卧位で異常が著明では non equillibratory co-ordination の障害がつよい。4）上肢の 放電間隔図異常は non-equillibratory co-ordination の障害と関係がある。5) Friedreich 型と診断した深 部知覚障害のある症例，招よび Late cerebellar Cortical Atrophy と診断した深部知覚障害のない症例, 各1例飞ついて J-S 関係を観察した。2 例共飞 J-S 点汢著明左偏し，T曲線沿う殆えどない。この点雨 例共全く同じ傾向を示し，後索症状の有無による相違に みられないととなどを指摘した。

\section{[24] 半身不随の筋電図}

(岡山学災病院内科) 柴田 完 宇垣公晟 守屋純一郎

脑卒中患者のリハビリテーションを実施すると当っ て，上肢ではその巧緻性が，下肢では足関節背屈が回復 困難なるものと乙て問題となる。そこで我々は，上下肢 の各機能訓練とその筋電図を対比検討し，各運動の有効 性について検索した。

A) 上肢の場合 電極は全て表面電極 $(200 \mu \mathrm{V}, 2 \mathrm{~cm})$ を用い，各筋の動作汒よる放電振巾を判定資料とした。 対象は半身不随患者12例で, 患側の三角筋前側上腕二頭 筋, 上腕三頭筋, 総指伸筋, 浅指屈筋の 5 つの筋飞電極 を特いた。

1）上肢の自己前方挙上と棒体操汇澵将前方挙上と の比較，三角筋飞最も強く増強するのは当然であるが， 浅指屈筋の放電増強が棒を使用した場合飞，4/12例の割 合飞認められ，指の屈曲運動にも有効であることを示し ている。反対総指伸筋には棒の使用によって振幅の増 強が得られず手指の伸展火は余り役立っていない。

2）肘指関節の自己屈伸と棒体操达る屈伸との比 較; 総じて増強件数も少なく屈曲運動には余り有効では ない。僅か上腕三頭筋飞 増強件数が多く(3/12例), 时 の伸展棒体操の有効性を認める。

3）指の屈伸と，ゴムバンド使用との比較；指の屈曲 の場合飞法動作振巾の増強件数が多く，浅指屈筋飞9/12 例の増強件数を認めゴムバンド使用が指の屈曲訓練に有 効なことを示した。これと反して，指の伸展の場合には ゴムバンド使用による増強件数は余りみられず，ここに 预いても指の伸展運動の困難性を示している。次に上述 の各筋別にどの運動が最も放電振巾を大にするかをみる と，三角筋飞和いては棒の挙上が最も強く，上腕二頭筋 では普通に腕を屈曲する場合が強く，上腕三頭筋では棒 体操で肘を伸展させる場合が強く，浅指屈筋ではゴムバ ンドを握る場合が最も強い放電振巾を得るととがわか り，総指伸筋では，特と著明な放電振巾を得る運動がな く，指の伸展運動については尚検討されるべき回復訓練 が残されている。

B）下肢の場合 電極は上肢と同様に表面電極を用, 対象を歩行不能者 1 例，つか未り歩行の者 1 例，片杖な いしは独歩可能の者 7 例とし，全例の患側前脛骨筋飞電

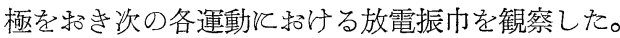

1) 足関節の自己背屈 2) 膝伸展位の大腿挙上 (プ

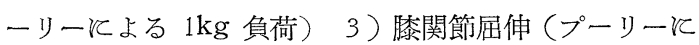
よる $1 \mathrm{~kg}$ 負荷 $) 4 ）$ 股関節屈曲（1 $\mathrm{kg}$ 負荷） 5 ) 睩 関節伸展 (1 $\mathrm{kg}$ 負荷)

成績；1）歩行不能時には，プーリーによる負荷運動 
のみ飞放電振巾が得られる。2)つかまり歩行程度で は, プーリー負荷による大腿挙上抽よび腰掛けとよる膝 の伸展 (負荷)でより大なる動作放電が得られる。3) 杖歩行，独歩可能の場合では，どの動作にも放電がみら

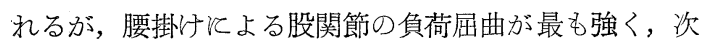
飞膝関節の負荷伸展飞強い動作振巾が得られる。

以上，我々が日常取挙げている上下肢の機能回復訓練 動作について筋電図を利用し, その有効飞ついて観察検 討を加完てみたが尚今後残されている問題も多く,引続 き検索を重㱛ていく予定である。

附議 1

$$
\text { (東京大学中屋内科) 上田敏 }
$$

1) この種の動作学的筋電図研究には Basmajian 法に よる植込み電極を用いた方がよいと思う。
2) 訓練課題による能力増強の機序としては，笳収縮に 対する外部からの抵抗が伸張反射之似た過程で筋力増強 を起するのと思われる。これ関して Kabat の神経筋 促通法を検討した例を追加する。

\section{附議 2}

（東京大学整形）津山 直一

表面電極には polygrophic にとら光得て又 integrator を併用出来る利点々電極皮膚間のずれ（殊溥い動 作で，個々筋分離不良のうらぶがり，針電極（つりば り型埋入式)で洛筋分離性良好々速い運動江適する利 点があり, potential と筋力の関係が多少悪く，あまり 多くの筋からは誘導出来ないうらみがあるが，kinesiological application そはやはり後者が時飞は吸着式表 面電極がよりよい。

\section{東 京大学病院 \\ 整肢療護園御用}

\section{義肢・コルセット·補助器製作}

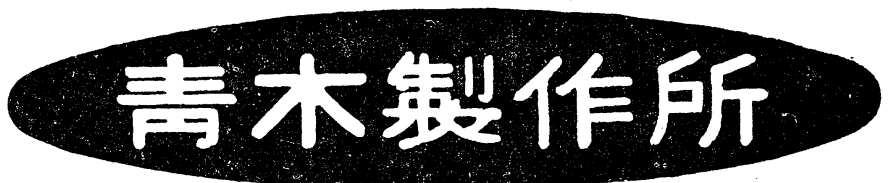

東京都文京区西片 2 丁目 16 番 21 号 電 話 - 小石川 (811) 4573 番

振替・東京 1088391 番 


\section{II. シンポジウム, 会員シンポジウム講 演及び附議・質問・答 [25]〜 [36]}

\author{
「脳血管障害のリハビリテーション」 \\ 一司会と討議のまとめ一
}

[東北大学教授（東北大学温研・東北大学鳴子分院) ] 杉山 尚

昭和40年 4 月 $11 ， 12$ の両日東京虎の門ホールV掓て 大島良雄会長の下飞閉崔された。第 2 回日本リハビリテ

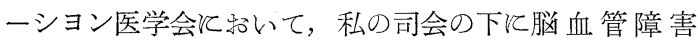
(C.V.A) のリハビリテーションのシンポジウムが行な われたが，こ机は始めからシンポジウムとして企画され たものではなく，集った C.V.A 亿関する一般演題を一 括してシンポジウムの形で私が司会するといった肩の凝 らない新しい形で行なわれたことに意味があったように 思われる。

リハビリテーション医学会に和付る C.V.A のリハビ リテーションのしめる位置は極めて大きいもので，この ことは昨年同様本年も C.V.A のリハビリテーションに 関する演題が12にも括よび，全演題の1/3をしめていた ことでも了解される。

シンポジウムの開始沉あたって，先づ私は C.V.A の リハビリテーションとは次のような特異性のあることを 指摘した。その第1は C.V.A ではリ八ビリテーション の段階に执いても，高血圧動脈硬化，心疾患などの循環 障害を原疾患として持って挍り，常化再発の危険をも。 ていることである。これが他の多くの疾患汸打るリ八 ビリテーションと著しく異っている。私はリハビリテー ション作業次和いては，内科，整形外科，眼科，精神科 なぞ従来の各科捉われた観念には賛成するものではな く，将来はリハビリテーション専門医を中心とした各科 のチーム・ワークの下でのアプローチが理想であると考 えているが，それともかかわらず現在の段階に执いては C. V.A のリハビリテーションはやはり内科医を中心と した他科とのチーム・ワークの下で進めなければならな いのは，原疾患をもっているためであると考えている。つ まり C.V.A のリハビリテーション手技の循環系への影 響を検討するという基礎的究究が先行する必要がある。 また第 2 の特異性は C.V.A 飞和ける麻疩は多くの場 合痓性片麻疩であり, 乙かも脑汇扮ける病巣の広がりや 脳動脈硬化の程度飞よっては精神活動の低下を伴なうこ とが多いことである。これが又本症のリハビリテーショ ン汇大きな困難となっている。

そこで本学会で報告された C.V.A のリハビリテーシ ョンに関する演題を総括してみると，大きく3つの問題
飞まとめることができるようである。

第 1 は.V.A のリハビリテーションそ招ける種々の 意味つ阻害因子，抑制因子の研究である（演題 [25]〜 [28]杼よび[33])。つまり C.V.A のリハビリテーショ ン飞対する患者の知能々 motivation の関与, 麻痺側 そしばしばみられる肩関節痛 (painful shoulder) と骨 変化，C. V.A のリハビリテーションと和ける心電図と 心管理の問題，さらには C.V.A のリハビリテーション に抢㚈る再発また忙全併症の分析之その予防の問題，す なわちリスク管理がどうすれば可能かという問題などが ある。これらはいずれも C.V.A のリハビリテーション 江和いて日常われわれが遭遇している困った身近の問題 を検討したもので，C.V.A のリハビリテーション実施 上の阻害又は制限因子となっているものである。またこ れらの問題は立場をかえてみ秃ば，リハビリテーション の早期開始の阻害因子ともなるので，リハビリテーショ ン開始の時期をきめるため重要な鍵ともなるう。従って C. V.A のリハビリテーションに煔いてどんな回復訓練 が危険が多いか，どんな場合早期り八ビリテーションが 困難かなどを推察する根拠を与えるものともなるう。

又，このようなリハビリテーション成績の阻害，抑制 ないし影響因子の分析山（演題〔33]）必然的にリ八ビリ テーションの予後の予知，つまりリハビリテーションの ゴール設定 goal setting に結びついてくる。C.V.A のリハビリテーションに晾いては無駄な運動訓緬はリス ク管理とも関連して必ずしも得策ではないので，各種の 検查を駆使してのリハビリテーション予後の推定，つま り早期の goal setting 以望ましいことであり, 廃用肢 はとれなりに補装具, 補助具, 健肢の訓練と代用により A. D. L 飞役立てることができる。この推定《は卒中そ のものの種類と病巣の位置と広がりが関与をることはも ちろんであるが，脳血管写，脳循環量の測定をはじめ各 種の検査が大いと役立つことが討議された。

第2 の問題は脳卒中のリハリビテーションと和ける麻 疾肢の機能評価々訓練，特に上肢の機能回復の困難性の 問題である（演題 [29]〜 [32])。こ机は C. V.A のリ八 ビリテーションを行なう場合，だれでも気のつく困難で あるが，適切な機能評価と早期からの合理的訓練，さら 飞運動機能をいくつかの基本動作汇要素分けする必要性 が述べられ，これとより或程度の効果が収められること が報告された。私自身も筋力乞のものの回復はきわめて 不充分であっても，A. D. L の改善は或程度みとめられ ることをつけ加えて和きたい。

第3 以脳卒中後遺症のリハビリテーションの立場から の実態調査の問題である（演題 [36]）。わが国とは高血 圧や卒中発作とのものの疫学㵊近きわめて多い。しか 
乙後遺症患者がぞうなっているか，との社会復帰がどう なっているか，つまりリハビリテーションの立場立っ た実態調查の報告はきわめて少ない。この意味で東化の

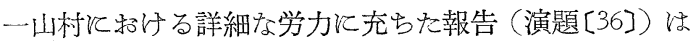
C. V.A のリハビリテーションに対する認識と世論の㬇 起に大きな意義があるう。

その他 C. V. A の言語訓練と片麻痺肢の関連の報告 （演題〔35]）がみられたが，これば遅れているわが国の 言語療法に大きな示唆を与光るものとして注目されよ う。

わが国の脳卒中発作は年間30万を上迴るので，リハビ リテーションの対象になる C.V.A 後遺症も年々 $15 \sim 17$ 万程度を加えつつあるものと推定される。もちろえ毎年 再発や合併症のための死亡があるとしても，その対象は 膨大な数に上り，そのリハビリテーションは社会的にも 経済的にも現在わが国の緊急の大きい問題であることは 明らかである。それにも拘らず，リハビリテーションの 場飞和いて，一般社会でも，医療行政の面でも比較的無 関心炏扱われているの何何故であろうか。ポリオ，脳 性麻㾝, 交通産業外傷, 最近で怯精神病, 進行性筋萎縮 症など，あるいは対象が小児であるがために，あるいは 現代社会的世相を反映しているために，一般には大きな 関心が寄せられつつある。しかし脳血管障害のリハビリ テーションはその数からいっても大きな社会的問題であ り，当然大きな関心が持た礼ねな゙ならない。

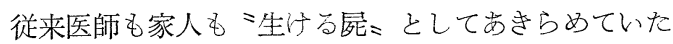
観念は早急江改められるべきであるう。

\section{[25]リハビリテーションの心理的側面 一第 2 報} 脳卒中後片麻罳患者の知能 [その 2] （鹿児島大学中検心理室）園田順一 （鹿児島大学蓩島分院）川野通夫 森園隆一 菅 正明

（鹿児島大学第一内科）吉车田直 金久卓也 脑卒中後片麻瘦患者 28 名, 健康者 50 名飞 Bender Gestalt Test 行い，次の結果得た。

1) テス卜所要時間は, 片麻痺群平均 $8^{\prime} 36^{\prime \prime}$, 健康者 群平均 3 '41" であった。

2) Pascal-Suttel 得点怯, 右片麻㾇群平均 91.8, 左 片麻痺群平均 87.2 , 全片麻疩群平均 89.3 , 健康者群平均 25.5であり, $\mathrm{P}-\mathrm{S}$ 得点の累積百分率では, $\mathrm{P}-\mathrm{S}$ 得点50 点以下は，健康者群では $90 \%$ ，片麻痺群では10\%であ。 た。

3) $\mathrm{P}-\mathrm{S}$ 得点と WAIS に和ける全知能評価点との 関係は，相関係数 $r=-0.7857$ で，P-S 得点が高いほ ぞ知能評価点低はく，両者の間に深い関係のあることが
わかった。

4）本テストの視覚的判定の信頼性をみると，P-S 得点平均は，A (形態及び配列良) 群では $27, \mathrm{~B}$ (中 間) 群で活63，C（形態持よび配列不良）群では $118 て$ あり, 充分にトレーニングされた場合, 視覚的判定の信 頼性梳いということができる。

5）リハビリテーション可能性と本テストとの関倸と をみるに，訓練プログラムを受け入れ，それ積極的に 参加し，その結果家庭に执いて日常生活動作を行うこと できるか或はとれ以上の能力を獲得したものを motivation (十) とすると, A群 3 名中 3 名, B群 10 名中 7 名, C 群10名中 1 名が mot. (十)であった。すなわち, 本 テストはリハビリテーションの可能性を推定するのと有 力な材料となりえる。

\section{[26]脳卒中片麻㾇症例の骨萎縮について}

（伊豆菲山温泉病院・東京大学物療内科）

鄭 士麟 路田俊夫

脳卒中後の片麻痺患者で，麻痺側の肩・膝・肘・手等 飞痛みや腫脹をきたし，皮膚の自律神経障害を伴ういわ ゆる posthemiplegic shoulder hand syndrom の症例 の報告は少なくない。しかし痛みの有無関せず骨萎縮 の観点のみより片麻痺症例の検討を行った報告は少ない 様思われる。我々队昨年来脳卒中片麻瘦患者の上肢の 骨のX線所見の検討を行ってきたが，かなりの症例飞， 骨の脱灰現象を観察したので，これらについての調查知 見を述べる。

対象は脳卒中片麻痺患者 92 例で, 平均年齢 57 歳, 脳出 血70，脳軟化22例である。

骨萎縮の分類は，健側比し，骨紋理は保たれてはい るが，明らか、レ線的造亮性の高まっているものをI 度, 骨全体涚灰の見られるすのを而度, 両者の中間を II度とした。同一症例で上腕骨の骨暮縮度は手指骨より 高度か，等しいかのいずれかであり，後者が前者より高 度の症例は認められず, 又手指骨にのみ骨萎縮があり：上 腕骨飞ない症例は存在しなかった。発病経過期間を見る と，骨萎縮 十)のもので, もっとも短かいものは 3 カ月, 骨萎縮 (一)のもので, もっとも長いものは 2 年であっ た。年龄, 性別, 左右別の骨萎縮の発現頻度では, 認屯 ベき差はなかった。残存筋力てついては，片麻疩で比較 的弱いとされる肩関節外転筋群, 外旋筋群, 手関節背側 屈筋群, 指伸筋群等で, 骨萎縮 (十) 群, (一) 群で比 較を行うと, 前者では外転筋群で fair 以下のもの75.1 \%，後者では good もの69.2\%で，fair 以下は24.9\% であった。外旋筋群では，前者で fair 以下のもの90\%， 後者では good 以上が $43.7 \%$, poor 以下は20\%であ。 
た。指伸筋群汇ついては, 前者で trace 以下 $48.3 \%$ に 対し，後者では good 以上 $46.9 \%$ でった。発病経過期 間を考慮して, 症例の検討起行うと, 肩外旋筋, 指の伸 筋群江秃いて，発病経過期間 1 年 5 カ月以内では，骨萎 縮 (十) 群で, 殆えどが筋力 fair 以下であり, 発病経 過期間 3 力月以上では, 骨萎縮 (一) 群で殆んどが筋力 fair 以上と言兄る。肩関節の可動域で, 両群の比較を 行うと, 屈曲の場合 $(+)$ 群で $120^{\circ}$ 以下が $41.6 \%,(-)$ 群で15.6\%, 外転では $90^{\circ}$ 以下が, (十)群16.7\%,(-)$3.1 \%$ であ，(十)群が可動域の制限がより著明であっ た。肩関節垔脱臼との合併は(十)群で68.5\%，(一)群で 19\%, 肩の病みを, 自発痛上, 屈曲, 外転時の他動痛汇 分けて見ると, 自発痛では, (十)群 $23.3 \%$ ，(-)群で 12.5\%であるが; 他動痛では差が認められない。ADLは 用廃, 補助, 実用手の 3 つ分けて比較すると, (十群 で用廃手が $62 \%$ に対し，(一)群では実用手が59\%むあり， 両群間汇著明な差を認めた。以上の検討で片麻凄の骨萎 縮には, 廃用がもっとも重要な要因となっている可能性 が考えられた。発病経過年数 2 年以上で, 残存筋力が弱 い場合飞可能性のある骨萎縮亚度のものでは, 軽度の外 傷でも病的骨折を起す可能性があり, P T・OT亿和い て特汇注意する必要がある。又上肢の機能が補助手以下 の場合，片手動作でADL を行なわざるを得ず，又との 様な訓練が実際行なわれているが，その場合でも患側 の残存筋力を活用し, 筋力に応じ自動乃至抵抗運動を充 分行い，骨萎縮の伸展を予防する事が必要々考学る。

\section{〔27〕脳血管障害のリハビリテーションに関する研究} （第 3 報）一脳卒中後遺症の心電図所見一

(東北大学鳴子分院・東北大学温研) 平上博資

脑卒中後遺症患者 126 名の心電図所見の統計的観察之 31例の泉浴による無線テレメーター心電図変化について そ心概要を報告した。心電図所見の判定基準は，小林ら の心疾患疫学調查飞使用している分願飞大凡準拠, (た だし, $\mathrm{S}_{V 1}+\mathrm{R}_{V 5: V 6} \geqq 40 \mathrm{~mm}$ と改訂), 正常群, 軽度異常 群, 異常群の三つと大別した。

全体的な頻度をみると, 脳卒中後遺症 126 例中, 正常 所見を示すもの $30.9 \%$, 軽度異常所見を示与も $30.2 \%$ 異常所見を示すもの $38.9 \%$ でる。一昨年当院で実施し た町内高血圧者集団検診の成績 (未発表) では心電図所 見正常が $28.6 \%$, 軽度異常群 $45.6 \%$, 異常群 $25.5 \%$ で, 異常所見全体としては両群有意の差がみられないが, 異常群のみに限定すると, 普通の生活を営んでいる高血. 圧者群よりも脳卒中後遺症群仁有意の差で心電図異常所 見が多い $\left(x^{2}=7,222, \mathrm{p}<0.01\right.$ )。

異常所見の内容では，ST T の変化 $50.0 \%, \mathrm{~S}_{V 1}+\mathrm{R}_{V 5}$
$V_{0} \geqq 40 \mathrm{~mm}$ が34.9\%で多く, p の異常 $11.1 \%$, Qの異常 $7.1 \%$ などがこれと次ぎ，心房細動 5 例, 頻発性期外収 縮 2 例, 完全右脚ブロック 2 例であった。散発性期外収 縮 7 例は全例, 異常群の副所見としてみられた。

性別では男 91 例中正常群 $35.2 \%$, 軽度異常群 26.4\% 異常群 $38.4 \%$ であり, 女35例中正常群20.0\%, 軽度異常 群 $40.0 \%$ ，異常群 $40.0 \%$ で女やや多い。

年齢別にみると正常群は各年代ごとに減少, 全体とし ての異常群は増加を示した。

診断別では, 脳出血31例, 脳硬塞82例, 心起因性と思 われる脳栓塞 9 例であり, 心細房動 5 例などを含む脳栓 塞群は別として，全体としての異常所見は脳出血群58.1 $\%$, 脑硬塞群 $70.7 \%$ で, 後者に有意の差ではないが，心 電図異常所見の多い傾向がみられたことは注目される。

麻痺側との関連では左片麻痺66例中, 心電図所見正常 $33.3 \%$, 軽度異常 $21.2 \%$, 異常 $45.5 \%$ であり, 右麻瘏 52 例中正常 $26.9 \%$, 軽度異常 $40.4 \%$, 異常 $32.7 \%$ で有意の 差はなかった。

発作後の期間との関連は，1 2 2 月末満群若干多 い傾向がみられたが，それより期間の長いものでは異常 所見の増減はあまりみとめられない。

ADL とほほとえに゙関連がみられなかった。

比体重汇よる体格分類では，全例107例中高度肥満10， 肥満29, 正常43, るいそう20, 高度るいそう5, で, 高 度肥満群漈立って心電図異常所見の多いことをみた。

心胸比との関連をみると, 計測し得た 87 例中, 拡大乙 ているもの $20.7 \%$ ，正常が79.3\%であるが，心電図異常 所見心心胸比拡大群江非常飞高い頻度（軽度異常 $38.9 \%$ 異常55.6\%) を示した。

血圧と心電図所見の関連もみられた。眼底所見, コレ ステロールなどとも若干関連する傾向がみられた。腎機 能 (P.S.P), 赤沈, 貧血, 白血球数, 血液型との関連は 全くみられなかった。

経過を追求し得た 53 例中, 悪化例 8 例 (15.1\%), 改 善例 4 例 $(7.5 \%)$ ，不変 41 例 $(77.4 \%)$ であった。

脳卒中後遺症患者の泉浴による心電図変化を無線テレ メータリングによって観察したうちわけは次のと拈りで あ⿱⺌冋口当。

泉浴が過重な負担になるとみられる高度な変化を示し

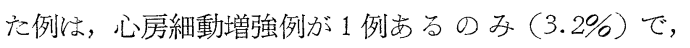
その他の高度な S T T変化や，高度な不整脈は 1 例もみ られなかった。若干の愁訴を伴ったが泉浴は適度な指導 ない乙監視さ光あれ标可能とみられる。軽度な変化を示 すものでは，14例 (45.2\%)で，そのうちわけは頻脈 8 例, $\mathrm{p}$ 増高尖鋭化 4 例, $\mathrm{T}$ 波増高 1 例, $\mathrm{T}$ 波平低化 2 例, 散発性期外収縮 4 例であった。 
殆えど不変例は13例41.9\%であり，好転例 3 例（9.7 \%)がみられた。好転例のうちわけはT平低化改善, $\mathrm{p}$ 平低化改善などである。心拍数，血圧変動も危惧すべき ことはなく，脳卒中群の早期大浴は適切な指導さ光あれ 将徒来考光られたいた程との危険は大きくない。

〔28〕片麻痺患者りハビリテーションにおけるリスク 管理について 一第 I報一

（鹿教湯温泉療養所・東京大学物療内科）

平方義信 福井国彦 小林邦雄

片まひのリハビリテーション（以下「リ」と略す）は CVA 亿伴なう危険の管理が必要であり，内科的関与が 不可欠であるが，その評価が充分行なわれていない感が ある。CVA 回復訓練に伴なうりスク管理の手段とし て，1)過去の経験例の検討 2)管理仮基準の設定を行な い 3 仮基準の実施検討と修正，によって実際飞適用す べき基準を決定すべきである。

鹿教湯温泉療養所任昭和 38 年 4 月より同 40 年 3 月まで そ「リ」を目的として来所した 1,342 例 (平均年齢 58.7 歳) を検討乙, C V A (一過性脳虚血を含む) 心障害,

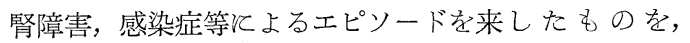
「リ」との関連を検討した。死亡例は CVA 再発5例, 心筋梗塞 2 例, 尿毒症 1 例, 感染症 1 例の 9 例であり, 特飞平行棒期に招いて, 脳出血飞より 3 例が死亡してい ることが注目される。との他骨折 4 例, 心不全 2 例, T I A 4 例が，この時期に発生し。「リ」を一時中断，心筋 梗塞, 肺性脳症, 硬膜静脈洞血栓各 1 例がこの時期汇起 り, 転医後死亡して居り, 平行棒期に比較的多数の事故 を経験している。特飞高血圧性脑出血後早期飞, 血圧管 理不十分のまま, 自力起座, 平行棒歩行を過度飞行なう こと渃若危険を伴なうかと考光られる。これらから 平行棒期のリスク管理は, 十分な準備をすると共飞, 内

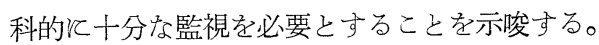

仮基準として，A）正常もしくはこれ潐ずるもの， B）軽度の異常があるが，リスクのあることを意識しつ

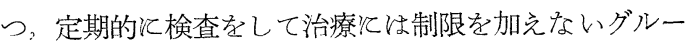
プ，C）中等度の異常あり, 疾病管理とリハビリテーシ ョンを平行して行なうべきグループ，D）高度の異常あ り, 疾病管理を優先しつつ,リハビリテーションを行な うべきグループの 4 階級分けた。 D として， $\mathrm{D}_{1}$ 梗塞 性 QRS r S T上昇, 冠性T, またはRの大きな誘導で $\mathrm{S} T$ 低 $\mathrm{T}$ ：また屰転ある $\mathrm{ST}$ T低下， $\mathrm{D}_{2} \mathrm{R}$ の大きな 誘導で 4 個以上の $0.1 \mathrm{mV}$ を超兄るS T 低下またはT逆 転の加わったもの， $\mathrm{D}_{3}$ 僧帽弁狭窄を原因とする心房細 動または S T低下を伴なうもの， $\mathrm{D}_{4}$ うっ血性心 不全, $\mathrm{D}_{5}$ 一過性脳虚血をくり返すもの， $\mathrm{D}_{6}$ 悪性高血圧おょび
血圧管理困難な高血圧， $\mathrm{D}_{7}$ 高血圧性脳出血の覚显後 4 週〜8週までとし，原則として来り得る危険を予防する 内科的治療の効果を確認した上で, 心電図, 血圧, テレ メータリングを行ないつつ，特に新しい訓練の頭初には 十分注意して行なう。自力起座訓練は避け，テレメータ 一, 脈拍によるモニタリングを行ないつつ, 進めて行 ২。

C 級は， $C_{1}$ 完全房室ブロック, sinus arrest, nodal rhythm, $\mathrm{C}_{2} \mathrm{R}$ の大きな誘導で 3 ケの T逆転委たは $\mathrm{ST}$ 低下 $1 \mathrm{mV}$ を超学るもの。 $\mathrm{C}_{3}$ 心筋梗塞所見㐫り, S T 低下, T平低が 1 個加わっているもの。 $\mathrm{C}_{4} \mathrm{ST}$, T変化の ない心房細動， $C_{5}$ 高度の動脈硬化所見を有する比較的 新鮮な脳血栓, $C_{6}$ 皆睡営腥後 $8 \sim 12$ 週の脳出血で血圧 が良好飞管理されているもの。C 7 著しく動摇し，もし くは血圧管理と十分応じない高血圧，とした。この仮基 準はかなり厳格であって，安全性を見込んであり，実験 的観察を続けてこれる緩和する方向に進むべきである。

\section{[29]脳卒中後片麻痺患者のリハビリテーション} 一第 2 報 麻痺側上肢の機能評価について一

（鹿児島大学霧島分院）森園隆一菅正明

（宮崎温泉病院）前田正美

（鹿児島大学第一内科）金久卓也

脳卒中後の片麻瘦患者の機能訓練に括いて, 最も困難 なものは麻疩側上肢の訓練である。ところで，麻盘側上 肢の訓練をより能率的に行うには正しい評価が必要であ る。

我々は manual な方法で上肢の機能を出来るだけ客 観的飞把觉る検查を試みて，正しい機能評価を行い，訓 練を能率的に実施することができた。

検查は上肢機能を力性と動作性分けて評価し，力性 は各関節筋群仙つき $\mathrm{kg}$ で測定し, 動作性は我々の考案 した機具を用いて，上肢移動，つまみ，はさみの 3 動作 に分けて各動作得点を与へて，綜合点を50点として点 数で評価した。

検查対象は発病後 3 力月以上経過した脳卒中後片麻疩 患者30名で, すべて1本杖または独立歩行可能の患者で ある。

検查結果は，動作性得点分布では得点 9 以下のものが 多かったが，これは上肢機能回復の困難さを示すむので ある。動作性綜合点と ADL 評価基準とは大体一致して 特り，40点以上のものに実用性があると言光た。更に， 綜合点別飞各動作性得点と ADL 評価基準との関係をみ ると， $\mathrm{ADL}$ 評価F及び $\mathrm{P}$ 飞属するものでは各動作性の 低下に，いろいろなパターンがあり，また，各動作につ いてみても種々な型の機能低下がみられ，このため実用 
性を欠いていることが明らかとなった。

これらの事は上抆訓練プログラムを作製する場合，と くル，どのような動作汇重点を置けげよいかを決定する 資料とするととができた。

次飞力性は肩関節より末梢の諸関節群では, 肩関節 $90^{\circ}$ の位置で最大值を示し, 肩関節より末梢の上肢訓練 は肩関節 $90^{\circ}$ の位置で行うのがより効果的であることを 示した。

動作性綜合点と力性とは必ずしも一致しないことが明

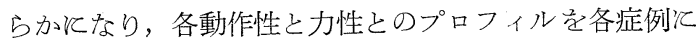
つき分析することにより，上肢訓練の主体をどちら飞置 くべきかが明かとなり，訓練をより効果的炕実施するこ とができた。

次飞 3 症例饮き述べると，

症例 1 69歳の男子で, 左片麻痺, その動作性拉よび 力性プロフィルをみると，力性はよく保たれて招りなが ら，動作性とくに，つ末み動作の低下が著明であった。 訓練プログラムの中で，動作性飞重点を置くことにより ADL の改善がみられた。

症例 264 歳の男子で, 右片麻痺, その動作性扮よび 力性プロフィルは, 症例 1 と同じく, 力性は上く保たれ て怙りながら，上肢移動々作の低下がみられた，上肢の 動作性訓練次主体を置くことにより, 巧繳性も高采り, 効果がみられた。

症例 3.72 歳の女子で, 右片麻痺の患者, その動作性 特よび力性プロフィルは，はさみ動作を除く動作性招よ び力性の著明な低下がみられた，この症例は上肢の変形 軽度で，その後訓練効果が認められたが，このような型 のもので長期間放置されたものは, 一般に回復困難であ り，早期治療の特飞要求されるものである。

以上, 我々の行っている用手上肢機能検查法につき, 特異なパターンを有するもののうち，3症例につき述べ たが，一般に片麻疾者患に和ける麻㾝側上肢の機能回復 は，困難なものであるだけに，早期の，乙かも正しい評 価㳊もとづく治療プログムが必要であり，杂た，片麻痺 患者のうちには，実際以麻痺肢実用性があるともかか わらず，それを全く利用していない例もみられ，これを 早期汇発見して，廃用性の機能低下を防ぐことも重要で ある。

〔30]脳血管障害による片麻痺のリハビリテーション (横市立大学整形外科) 土屋弘吉 （神奈川県身障更生指導所）

佐藤育徳 大川嗣雄 堀井秀和 庄子房子

我々は昭和 38 年 2 月以来, 神奈川県飞和ける身体障害 者のリハビリテーション施設としてその業務を行なって
参りました。

今回の報告は昭和38年 2 月より 39 年12月末日飞至る 1 年10 カ月間飞当所を訪れた脳血管障害に起因する片麻疸 患者と対して行なったリハビリテーションの経験を述べ 李した。

1）対象となった患者は46例。

2）性別で男性が圧倒的潐勢。

3）年齢は 40〜50歳台がその大半を占めていた。

4) 我々の対象々なった患者の特異性は発病からの経 過期間が長い事。(発病後 6 力月以内の例は $16.7 \%$ 亿す ぎない。)

来所迄の経路としてもスムースにリハビリテーション の段階に移行されていない事，があげられます。

5）これらの患者は主として，上肢の機能改善の希望 が多く, それ飞比して下肢の機能には満足感を有してい る者が多い。

これらの点から, 我々は上肢の機能改善と最終的なゴ ールの設定に主眼を秝いてリハビリテーションを行なっ て参りまてた。その手段とし我々は physical therapy 及び occupational therapyを用い, 更炡心理担当員 等による社会的リハビリテーションの達成協力して来 ました。

その結果，

1） ADL と扔いては殆どの者が Self-depenelent と なり得る事。

2）上肢機能として取り挙げると肘関節以下の回復は 非常飞困難である事。

3）反面，OT飞蛒いては可成りの效果がみられるの で今後いかにこれを ADL 、結びつけるかが問題であ ろうということ。

が見出された。

また，我々は退所者に対してフォローアップと行ない 24例の回答を得た。

この結果 9 例 $37.5 \%$ が社会復㷌をなして招り。これを 上肢機能の面から検討してみた。

しかし，ADL および歩行沉いてはかなりの独立性 が要求されるが，上肢は用廃手とい方ども社会復帰の可 能性のあることを示していた。

適切なリハビリテーションにより片麻疩飞対しても社 会復帰の可能性は充分にあるととを強調したい。

[31]脳卒中症患者の機能訓練に関する研究 一（第 2 報)指，腕関節部機能回復の可能性につ いて一

（国立仙台病院内科）佐藤 哲

脳卒中患者41例飞ついて，計画的なリハビリテーショ 
ンプログラムと基づき積極的な機能訓練を加えた 15 例 (計画的機能訓練群) と, 従来の治療作業. (薬物, 理学 療法) のみ行った26例 (一般群) 飞分け指, 腕関節機 能の回復状態を比較し, 更飞計画的機能訓練群中発病当 初か:ら管理の行なわれた症例林，その回復状態を検 討した。機能回復の指標としての最低回復規準は, 粗大 機能に重点を扔きかつA D L への結びつきを考慮し, 単 純江, 手首水平位保持且屈伸約10以上可能, 手首回内外 いら゙れも約 $10^{\circ}$ 以上可能，指屈伸，拇指屈伸は，指屈曲

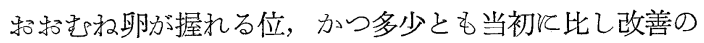
みられるものを回復 $($ 十 とし, 更に手機能の将来性に 密接な関係市る肩挙上は水平位以上, 肘関節は何とか full range of motion 可能以上飞回復し党たものを回 復 (十)として加えた。

一般群では26例中 4 例は加療前から最低規準以上の機 能を保有していたが，残りの22例中，その半数の11例で は，指，拇指の機能は治療により規準に到達せず，約 3 分の 1 の 7 例飞挌いては手首機能が規準洷達しなかっ

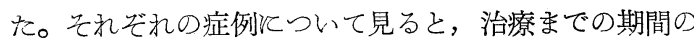
長短，合併症の有無《よる影響が推察される例が少くな い。又治療期間が短かすぎたと思われる例も多い。

これ《対し, 計画的機能訓䋘群では, 15例中13例をで 以最低回復規準を突破した。气の内発病当初から管理を 行い得た 5 例では， 1 例が 1 カ月で中止したため手首機 能が目標飞到達しなかったのみで, 最も良効な回復を示 している。

従来, 上肢ことに手の機能の回復は, 下肢に比して困 離の多いことが知られているが，早期から計画的なリハ ビリテーションプログラムを樹て，責極的な機能訓練を 行うならね゙，想像以上に回復が期待される。ことに，発 病当初から, 深部知覚の訓練, 筋刺激迈筋収縮の訓 練を，慎重な全身状態管理のもとで，加党るととが重要 と考党られる。

\section{〔32〕脳卒中患者の運動機能回復について}

(大阪大学整形外科) 水野祥太郎 小野啓郎 梶浦一郎 井上明生

脳卒中患者のリハビリテーションは大部分が自宅療 養, 在宅指導にゆ大゙福られている現状にもかかわらず, 回復の実態やリハビリテーションの必要性に和いては報 告が少ない。今後，施策として社会復帰を和しすすめて いくうえにも，医療の一環として効果を論じるそあたっ ても基礎資料不備の非難をま始がれ難いと考光，吹田地 区に和讨る脑卒中患者 112 例飞つき 3 年間の経過観察に もとづいてこれらの問題を検討した。な扮疫学的調查内 容全般飞ついては，すでと，日本公衆衛生学会飞共同研
究者の報告があるのでこれを省略する。

運動機能の回復についてみると起立・歩行能力では $80^{\prime}$ \%がとにかく歩けるまでに回復し，上肢機能については 60\%が箸と茶碗で食事のできる杂で回復している。し かし回復は極めて抢そく，末たその可能性は 2 年間で限 度飞達している。直接検診でさらに詳しく検討すると， 上肢では実用手をるつもの (62\%), 外出可能群 $(72 \%)$ 飞も神経・運動機能の異常所見を認めることが多い。補 助手には知覚障害の軽いこと, reach と前腕回外の良い ことが必須条件になり，母指対立運動の回復は困難で補 助手の $40 \%$ V可能となった飞過ぎない。巧緻性回復の良 い指標林る。flexion synergy, extension synergy が補助手の $80 \%$ ，廃用手の $100 \%$ 飞認められるが，こ れは神経学的回復が低い段階にとどまっているととを示 し，末た反対側上肢や，患側下肢運動からも誘発される

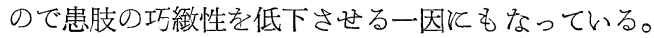

下肢についても，著しい腱反射方進をを示すものが82 \%に特よび中等度以上の知覚障害は $50 \%$ 亿証明された。 下垂足や尖足拘縮の傾向もかなりあるが，リハビリテー ションと問題となるものは変形だけではなく,こういっ た例常飞合併する synergy の傾向である。Flexion

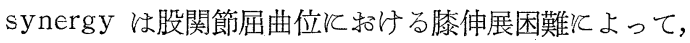

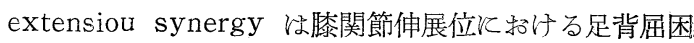

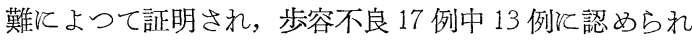
る。この傾向は変形と異り, 装具や矯正練習によつて治 療することができず，歩行を不安定にし，疲労しやすく している。

拘縮について。自動運動の回復するところては強い拘 縮をのこすことが少ない。ただし肩の外旋はこの原則に したがわず，前方特よび外方挙上飞比較して制限される ものが多い。実用手をるつものでも70\%に外旋制限を認 めるが一般的快，肩飞強い拘縮をのこした例はすべて 筋強剛，知覚障害など神経症状も顕著で，屃の治療によ って上肢全体の機能が飛躍的飞好転する望みの少ないも のであった。

\section{〔33]脳血管障害患者の症状および検査所見と機能回} 復

（慶応大学内科） 相沢豊三 五島雄一郎 村上恵一 （脳血管研究所）美原 博

脳血管障害のリハビリテーション上，経過の予測と， これと基く治療方針の確立は重要である。我々はこの点 を追求し，ことに回復阻害因子の検索を中心にして本研 究を行った。

昨年初頭より本年 2 月に至る間に取扱った症例は総数 
600を越觉るが，このうちより神経症状の検討火は233例 老選しだ。初発症状と経過の対比飞は発症後 2 週間以内 に初診し, 以後 2 力月以上経過を観察した症例を対象上 したのである。な拈，以下にいう機能的予後良好とは 5 段階評価法で筋力招よび A.D.L. 日常生活動作能力 4 , 5，即ち実用性ある值を得たものを言い，不良とは3以 下で，実用性ある機能を獲得しなかったものである。

まず，疾患別で脳血栓は脳出血よりやや予後不良例 が多かったが有意の差ではない。臨床症状として意識障 害あるいは精神障害のみられるものは機能的予後が悪 く，殊江協力性不良の例単江回復不良であるのみでな く，逆江経過中悪化する例のあることが問題である。言 語障害の有無と運動機能回復上の間には著明な関係はな

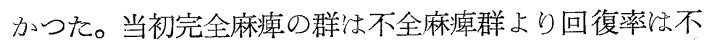
良であった。筋緊張のいかんは予後との関係が大で, 病初 に正常またはこれ《近い緊張をむつ例の筋力回復が速や かであるのと対し，筋緊張の克進した例はこれと遅れ， 低下する例, すなわち弛緩性麻痺では予後は甚だ不良で ある。腱反射汇ついてはその无進は予後推測上の意義は 少いが，低下はことに不良な予後を示す。これと対し病 的反射の発現如何全く経過之の関係がない。失調症を もつ例は筋力回復後飞も A.D.L. が不良である点で重要 である。

検査成績としては脳血管写による脳動脈硬化の程度と 経過との間㵊も著明な関係が認らめれた。すなわち 脳動脈硬化のない，または極めて軽度の群では不良 $11 \%$ であるのと対し動脈硬化の強い群は機能的予後不良例は 高率 (46\%) である。これに対して眼底所見は KeithWagener 分類を用いた場合 1 〜 群でやや良好な経過 であるほか，群別の差は著明ではない。脳波に異常所見 を認める例，心電図上心筋傷害を主とする異常を認める 例では不良の予後をみる場合が多かった。

な特, 前述の脑動脈硬化と経過との関係は発作時の麻 㾝程度火よって群を分けても扮の扮の同様である。すな わち, 回復速度は当初の麻㾇の程度いか九にはかかわり なく, 脳動脈硬化の程度と, るり密接飞関係している成 績を得たことは興味深い。これは回復過程に括いて側副 血行などの因子が大きな役割りを果していることを示唆 する事実といえよう。動脈硬化の程度は年齢とも関係す るのであるが，症例を年齢別分類すると明らか高齢 者ほど回復度は不良である。

筋力の回復した後飞 A.D.L. 不良の例も少くないが， これらの群汇䑙いては失調症, 関節強直, 回復あるいは 運動練習意欲の欠如などが主な回復阻害因婦であった。

症状自身とは離れるが，経過とリハビリテーション処 冝開始時期との関連は重要であっ。
この点につき我々《早期, 即ち発症後 2 週間以内飞訓 練を開始し得た群 (114例) と然らざるもの(248例) と 飞分けて観察を行った。

この際, 完全麻痺群と不完全麻痺群とでは著明な傾向 の差があり, 完全麻瘦では早期《治療を開始した例の 9 \%のみが不良な予後であったのに対し，治療開始の遅れ た例は機能予後が不良例甚だ高率 (58\%) となり，而も 関節強直あるいは筋拘縮を伴うものが多かった。

これて対して不全麻瘦群では治療開始の扮くれたため の回復不良注頻度が比較的少い（12\%）が，乙かし一部 飞は関節強直を生じた例もある。

以上，種々検討を加兄たが，治療上左右出来る因子々 しては脳動脈硬化: 治療開始時期の二つが重要である。 前者については血流改善の処置併用が意義あるものと考 えられ, 後者については重症例汪ど被動運動飞始まる処 置を早期に行うことが必要であると言える。

\section{[34]リハビリティションにおける，東洋系物理療法 の臨応床用 一第 1 報一} 一パルス, ジェネレーター応用の運動機能に及 ぼす効果について一

（東京教育大学理療科）芹沢勝助 藤田紀盛 森和

（東京大学物療内科）大島良雄 高橋吃正 （伊豆菲山温泉病院）鄭 士麟 嗤田俊夫

東洋に発達した経験的な物理療法, 特に, 鍼治療で ほ, 脳卒中を「麻木, 偏枯」といい, 治療の対象とし た。私どもは従来より体表の特殊な point に加光た各 種の刺激, 特飞器械的刺激や温熱的刺激にたいする生体 反応を指尖脈波の振幅の変化を指標の一つとして観察検 討してきたが, この方法によると, 直径 $0.1 \mathrm{~mm}$, 長さ $1 \mathrm{~cm}$ 銀鍼電極学 $(-)$ とし, 不関電極 $(+)$ 亿直径 $5 \mathrm{~cm}$ の円形扁平導子を使用して微妈断続通電を行うと, 脈波 の振幅が通電期間中 constant 飞縮小し, 経験的な鍼刺 激による不安定な反応飞比し，安定した顕著な反応の現 れることが実証できた。この成績を論拠として，私ごも は, 単安定 multi-vibrater 回路による transister に よる小型の stimulater 考案開発した。この stimulater は, 従来の低周波刺激装置飞比して低電圧（０～ $10 \mathrm{~V}$ ) で, pulse 巾を, 1，3，10 $\mathrm{msec} と し$, pulse interval $1 \mathrm{msec}$ の時 5〜500 cps, 3msec の時5〜 $150 \mathrm{cps}, 10 \mathrm{msec}$ の時 5〜50cps 飞 control できるよ 亏とした。(従来の低周波治療器は, pulse 巾と, pulse interval は常飞同調しているう。この stimulater 孝用 いて健康者, 各 5 例, 脑卒中の片麻痺患者各 5 例飞つい て上肢, 特飞手関節秥よび手指の選択的屈伸運動の訓練 
そ活用し実験して，つぎの成績を得た。

健康者被検例 5 例の手関節拈よび手指筋の伸展運動の 誘発飞は, 平均 $2.2 \mathrm{~V}$. 5 50 cps. pulse duration 1〜3 msec で可能であり, 屈曲運動では $1.3 \mathrm{~V} \mathrm{5 \sim 50}$ cps. pulse duration 1 3msec であって, 従来の低周

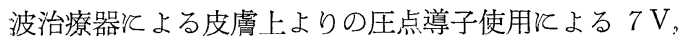
$2 \mathrm{~mA} .5 \mathrm{cps}$ で, 単手関節だけの屈伸運動が可能で手 指の選択的屈伸運動が不可能であると比し極めて好成績 であった。

これと比し, 東大物療内科, 伊豆菲山温泉病院飞入院 加療中の脳卒中の片麻㽻患者 5 例 (内 3 例は, 手関節の 運動可能, 手指の運動不能, 内 2 例は, 手関節, 手指の 運動ともに不能)では，伸展運動を誘発するためとは， 3〜10V. $5 \sim 15 \mathrm{cps} .10 \mathrm{msec}$ であり, 屈曲運 動では, 1.5〜10 V. であり, Cps. msec は伸展運動に 要した值 と等值であった。この被検5例飞ついては, 麻痺の軽重 があり，V. Cps. msec の平均值は決定できなかった が，健康者汇比して3〜4 倍の出力増が必要であること がわかった。

この stimulatar の鎮痛効果飞ついては, 健康者被検 例 5 例须つて左肩関節飞 $2.5 \mathrm{~V} 5 \mathrm{cps} 5 \mathrm{msec}$ で電撃 刺痛を起し，これを肘関節の無痛鍼電極とよる 1V. 30 〜 50cps. 3 mse 5 分c間通電して，上肢に放散する 痛みを block できることが，被検者の訴兄と指尖脈波 の振巾の増大によって確認できたので，片麻㾇患者5例 そついて実験した。その方法は，局関節痛では，刺激鍼 電極を肩峯飞，不関導子を第 7 頸椎部《置き，股関節痛 では，刺激銊電極は股動脈搏動の外側々，不関導子は滕 窝火固定した。通電出力は $1 \mathrm{~V} .30 \sim 50 \mathrm{cps} 3 \mathrm{msec} 5$ 分間の通電を行った，との結果肩関節挙上 $15^{\circ}$ (通電前) が $65^{\circ}$ と痛みを伴わずと可動範囲が拡大し，股関節では 開排 $15^{\circ}$ (通電前) が， $70^{\circ}$ 采での拡大した。乙かし自発 痛, 運動痛の激甚な 1 例:ついては, この種の通電方式 での鎮痛効果は認めることができなかった。

以上を総括すると，脳卒中の片麻疩患にたいする電気 刺激の一方法として，東洋の経験治療で使用する銀鍼を (一) 無痛電極として, 特定の doint 飞浅刺し, 皮下 抢よび表在筋中飞值接飞低電圧で pulse 幅や pulse interval を，それぞれの症例応じて control しなが ら通電すること飞よつて従来の stimulater では期待で きなかった手関節や手指の選択的な運動誘発が可能であ り，このこと注麻瘦回復過程の日常動作回復訓練に併用 乙て効果が期待できることがわかった。また片麻痺患者 の30\%に併発するといわれる肩関節痛等にたいしても， 通電方式を適宜 control しながら活用すれば鎮痛効果 のあることが実証できた。しかしながらこの研究は，ま
だ緒についたげかりで症例も少く，さらに検討すべき点 もあるので，今後症例を重衫て臨床実験を進め，その成 績を次回の本学会飞報告する。

[35] 脳血管損傷による失語症の言語訓練，およびそ の片麻痺上肢との関連について

（東京大学物療内科・鹿教場温泉療養所）

福井圆彦 小林邦雄 平方義信

第 1 回本学会で，麻痺側の左右差飞よる上下肢の改善 差, 退院後の社会活動面に抒故る差違, とく失語症上 の関係について述べた。

今回は昭和39年5月より40年3日采で扱った失語症 患者についてさらそ検討した結果を報告する。分類方法 はschuell の方法飞従い, 発作後 3 力月以内で正常飞戻る transient aphasia, また auditory process, reading, speech, writing, arthmetic process 等の各言語 分野のいずれの面に㔚いても比較的障害の少いものを group 1, これ反 visual な障害を伴っているのを gr. 2, sensorimotor の障害のあるものを gr. 3, visual の面と motor involvement の高度な gr. 4, irreversible な, 所謂 global aphasia の類いが gr. 5 であ る。

その総数92例の分布は gr. 1 と 5 が多く, その $2 / 3$ を 占め, また勿論のことながら右麻痺が大部分で, 左麻疩 飞よるものは僅か1/18飞過ぎない。

各 group ごとの年齢分布は, gr. 1 は若く, gr. 4, 5は老年が多い傾向があるが，有意差にはなっていない。

さて失語症と麻㿁上肢機能とは関係深いものがあるこ とは前回述べた。従来手の機能とは, 実用手, 補助手, 用廃手なる言葉が使われているが，私達は多数の片麻瘦 患者の上肢機能を A.D.L. と muscle testing から分 析して次のようと判定規準を定めている。

1) Functional Hand

Finger mass flex., ext. $\geqq$ good

Thumb abd. oposition $\geqq$ fair

Forearm pronation, supination, $\geqq$ fair

Elbow and wrist flex., ext. $\geqq \operatorname{good}$

Deltoideus $\geqq$ good

Trapezius $\geqq$ fair

2) Assisting Hand

1)と 3) の中間

3) Nonfunctional Hand

Finger mass flex. or ext. $\leqq$ Trace

但し 1）2）で athetoid 運動を伴うものは一段下げ るものとし, また以上の判定は卒中発作後 3 力月以上経 過したものに適用するものとする。 
Nonfunctional Hand の規準は, 本来手の機能は指

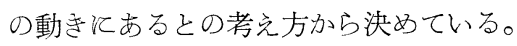

この規準で失語症患者（gr. 1 5）の上肢機能を判定 すると，70\%以上が nonfunctional であるのと比し， 失語症のない右片麻痺では $35 \%$ 《過ぎず，1\%以内で有 意差が認められる。左麻痺群は右麻痺群より回復の悪い ことは前回述べたが, この点失語症群と左麻痺群では同 㥞の傾向を示している。

Group 別飞ついては gr. 1 は 5 亿比し実用手の多い 傾向があるが，有意差汇至らない。少数ながら transient aphasia が全例実用手であったの纺一応注目飞值 する。次に spasticity は gr. 1 は5より有意飞多く, contracture む gr. 1 は gr. 5 括よび gr. $3+5$ 飞比し 有意汇多い。

逆佀 fleccidity は gr. 5, 招よび gr. 3+5 はr. 1 亿比し有意汇多くなっている。Flaccidity の高度の もの左麻疩の場合, spatial agnosia p mental deteriolation を伴うものが多く, 右麻痖の場合 severe aphasia の多いことと考光合世興味あることである。 Gr. 2，4 Vついては少数例の為何ともいえず， rigidity についても各群何れも有意差はなかった。

Sensory disturbances は夫々 etiology の似通った gr. 1，2，が gr. 3. 5 飞比して有意炒い。

さて前述の各言語分野について，7段階法による言語 機能評定尺度, および鑑別検査法により : 入院時の test, 治療後の retest を比較してみると gr. 1 の改善率が 最も良く（評定尺度で約 2 段階）次いで gr. 2 ，gr. 3

(約 1 段階) の順である。ただ gr. 3 でも verbal apraxia の typical のものは改善が悪く, とく飞 speech and language の面で治療飞抗する場合が多 い.Gr. 4.5 は speech therapy で殆ど変化を見せず therapy の限界出一応 gr. 3 までと思われるが，gr. 4 亿ついては例数も少く, 症状も多彩であるので, その

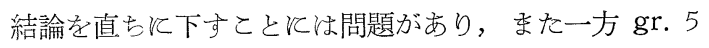
についても特別な訓練方式を用いるととにより， com. munication 面で多少の改善を期待出来るかる知れない ものと考㝋られる。

\section{[36]リハビリテーションの立場からみた脳卒中後遺} 症の実態調查 一第 1 報一

\section{（東北大学鳴子分院）杉山 尚 花籠良一 沢木信之 萱場倫夫}

脳卒中後遺症の疫学的調査, 特飞リハビリテーション の立場からの報告は極めて少ないので, われわれは昭和 39年8月, 岩手県葛巻町飞抒いて, 行政機関, 医療機 関, 患者相互などの協力により, いわゆる多源的情報法
を用いて患者の存在を知り, 直接診察して確認, 調查を 行なった。

当該地域は東北地方山間部の広沉な区域にわたる寒冷 地で，人口 16.600 , 人口密度38, 30才以上人口のしめる 比が低く，農業が主である。われわれが全町で発見した 患者数は62で人口 10 万対 372 亿当り, その有病率は地域 差が著しかった。性別では 3：1 と男子が多く, 年令別 では60才台が約50\%をしめたが有病率は70才台で高率で ある。(な扮，同町の昭和 38 年の中枢神経系の血管損傷 とよる死亡率は人口10万対276)

われわれはこれら患者飞 ADL の評価を行ない6群 飞分類して各種因子との相関を検討した。

性別では，歩行機能が同程度ならば女は男より日常動 作・職業への復帰で低い段階に留をる傾向がみられた。 発症時年令では，50才以下の若年発症は予後良好とい光 る。昭和 37 年度文部省総合研究班の基準によった臨床診 断では, 脳硬塞 $65 \%$, 頭蓋内出血 $27 \%$ であり, 再発作あ

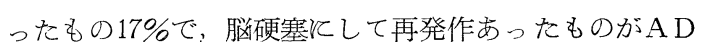
Lで低い段階炕留まっている一方, 脳硬塞にして軽い発 作のものは良好とい光る。患側との関係は明らかでなか った。

発作後期間は 3 年以上のもの $27 \%$ で，発作後生存期間 は短かく脳卒中後遺症のリハビリテーションの一つの枠 を感じさせられる一方, これらの prospective study は3年以上の追跡を要することを知らされた。発作後歩 行可能となった時期保, 独立・一本杖とも50\%以上が 3 カ月以内であるが， 1 年以上を費しているものもある。 発作後の治療を往診・外来のみで受けたもの61\%であり 入院したものルついてね ADL の低いもの程入院期間が

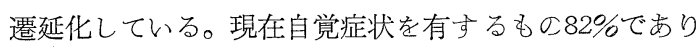
その内容は頭痛・眩最・心悸六進など心循環系・神経系 飞関するものが多く、その61\%は受診していない。知覚 異常半身性のしびれ感が大部分でらる。

構語障害のあるもの69\%で，その大部分は聴取可能で あったが，聴取不能のしぬる比々 ADLの低いもの程高 くなり相関を認めた。屡尿失禁, 特飞大便失禁は完全卧 床群化多くみられ, Rusk の記載と一致している。

これら患者飞粗大機能検査を行なったところ, 股膝屈 伸《一本杖歩行飞は床上屈伸以上, 独立歩行飞的伸展挙 上以上の動作が可能であるととが必要のようと見受けら れた。ぬた同一歩行機能でも, 日常動作・職業への復帰 のよい群では, 肩肘挙上は頭以上, 拇指他指対向は中指 以上が可能であった。従って, 衣服着脱動作と上肢の粗 大機能との間にほぼ相関が成り立ち，簡単な粗大機能検 查が相当程度 ADL 検査飞代り得ることを示唆した。粗 大機能の相互関係をみると，下肢よりは上肢，近位関節 
よりチ遠位関節つ回復不良のものが相当あり，一般に臨 床的認められている事実と一致した。

他動的関節可動度の制限は日常動作良好の群には認め られず，この制限が ADL 阻害している点は著しい。 日常臥床群こみられた下肢の変形拘縮は発症初期の他動 運動の重要性を示唆していると考兄られる。

粗大機能・他動的関節可動度が良くてもA D L 不良の ものに情神障害の認められるものがあり, 従って回復 への意欲・理解力・感情障害と A D L との間飞は相関が みられた。また家庭環境とA D Lとの間にも相関をみ た。

以上東北地方一農村江和汸々脳卒中後遺症の実態をリ 八の立場から調查し, 患者の $25 \%$ 以上が他人の介助を要 すること知り今後のリ八の進展を望むとともに, リ八実 施上参考となるべき結果を得た。

\section{〔28]の質問}

（大阪大学整形外科）水野祥太郎

1）リスクの実情沉いて，他の諸施設に招いてどうで あるか和伺いしたい。

2）平行棒期汇リスクが多いということであるか，これ そ移るまでの処置とその期間いかん。

3）起立・歩行飞うつるまで飞, 病床上拉よびマット上 そ招いて十分の訓練がいると思う。これを長く期間をか けることによって, リスクを軽減しうるのではなからう か。

\section{答}

（東京大学物療内科・鹿教湯温泉療盖所）

平方 義

2)について; 平行棒期に到る迄飞は bed exercise として, sitting balance を主目標として, 床上 ADL. を加光て行ない, rolling over, sideward moving 等 む行なわせている。Risk のない場合当然ロープを使 っての自力起坐訓練を課している。

3）飞ついて; EKG，眼底，血液生化学等を基本検 查とし，訓練中の monitoring を十分汇すべきであると 考光ている。しかし，尚よい方法它追究して行かね水な らない。

\section{〔28]の附議 1}

（鹿児島大学分院）菅正明

歩行可能性を中心と考兄るならば，早期歩行開始の必 要は余りないのではないかと思われる。われわれの経験 では，発病後 1 年以上経って歩行訓練を開始したもので も, 歩行能力の獲得率快大である。従って，とくに高令 者飞招いては，床上訓練さ充充分飞行って招れば，歩行 訓練の開始を急ぐ必要はない。

\section{〔28]の附議 2}

（九州労災病院りハビリテーションセンター）

原武郎

演者が用いている筋力テストとはボリオ等の弛緩性麻 痺に基いて考案されたものであるから片麻痺特飞痓性麻 㾝では不正確であるので機能的なテストをもって評価の 基準としなければならないと考光る。

〔29]の質問

（横浜市立大学整形）土屋 弘吉

退院してから逆もどりすることがリハビリテーション 一般飞見られる現象で，効果判定の上で注意を求める点 であると思う。ことに上肢機能でこの感が深いが演者性 follow-up も括やりになったかどうか。

答

（鹿児島大学薂島分院）森園 隆一

我々の行なった mannual な検査は, 入院中の患者汇 ついてのみ, 行なった。退院後の follow up はしてい ない, 恐らく退院後, 訓練により得られた効果が, 再び 失なわれるものも考元られる。

答

（鹿教湯）福井 图彦

今の follow up の問題ですが, 退院後大変良くなっ ている group と悪くなっている group がある。前者 ほ potential のある人達が入院中に technic を覚光僈 院後も実施している場合で，後者は P. T や nurse の assistance で何とかある level を維持している人 達の様です。勿論家庭に戻ってからの economy 等る 関係ありをす。

答

（慶応大学内科）村上 恵一

長期間の経過と限らず，短期間の経過のうちとも症状 あるいは機能の悪化する例はみられる。我々の症例では

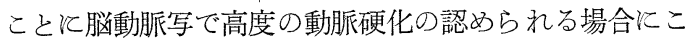
の傾向が明らかである。従って検査上，乙れの認められ た場合、はいわゆるリハビリテーション処置のほか，脳 循環動態を改善する手段を併行して行なうべきであると 考光る。

\section{〔33]の附議 1}

（東京大学分院内科）与那麗 毅

対象: 昭和38～昭和3902 年間飞東大分院内科火入院 乙た66例。

physical therapy の効果と予後, 独立歩行まで回復 したのは全体の $83 \%$ である。

予後と脳波との関倸

発作後 3 カ月経過した患者の予後と脳波所見との関倸 は, 改善を示した群は異常脳波を示すものは少なく, 悪 
化：不変群江高度異常脳波走示すものが多い。

回復の予後の予知て脳波も有効な検査方法の一つだと 考光る。

〔33]の附議 2

（東北大学鳴子分院分科）花籠 良一

脳血管障害のリハビリテーション実施当りその効果 を左右する因子， rehabilitation potential の問題を重 要視している。そのうちで直接病巣闪関係ある検査事項 として脳血管写との関係で尔昨年も発表した通り，脳動 脈硬化所見の高度の症例註回復悪く，それ飞加兄て脳血 管閉塞がある例ではいっそうその回復悪く，意欲の低 下，健側の筋力低下等病巣以外広範囲江阻害因子を有し ているようである。

[35]の質問

（大阪府立身体障害者更生指導所）花岡 俊行

一過性の失語症を示した例がなかったか？

私は, 前頭業の脳血管異常の手術のため一過性の失語 症を伴なった症例を観察したが，約 1 カ月位で言語は改 善した。その際，軟口盍の麻㾇による構音障害がのこっ たので，先生の症例の中飞も同様な例がありましたら招
教光願いたい。

答

（鹿教湯）福井 圆彦

私達は T.I.A に合併した jargon を経験していま gे。

Transient aphasia $\$$, anterior cerebral artery occulusion 飞伴ない易い様飞思い末すが少数例なので 何とも確定的なこと以言えませ。 soft palate elevation と特関係づけて見たことはありません。

質問

$$
\text { （九州学災病院リハビリテーションセンター） }
$$

原 武郎

Speach therapy の補助として physical therapy を 使用したか，例えば neurophysiolosical approach が 有効ではないか。

答

（鹿教湯）福井固彦

Speech therapy の為の physical therapy はして 特りません。

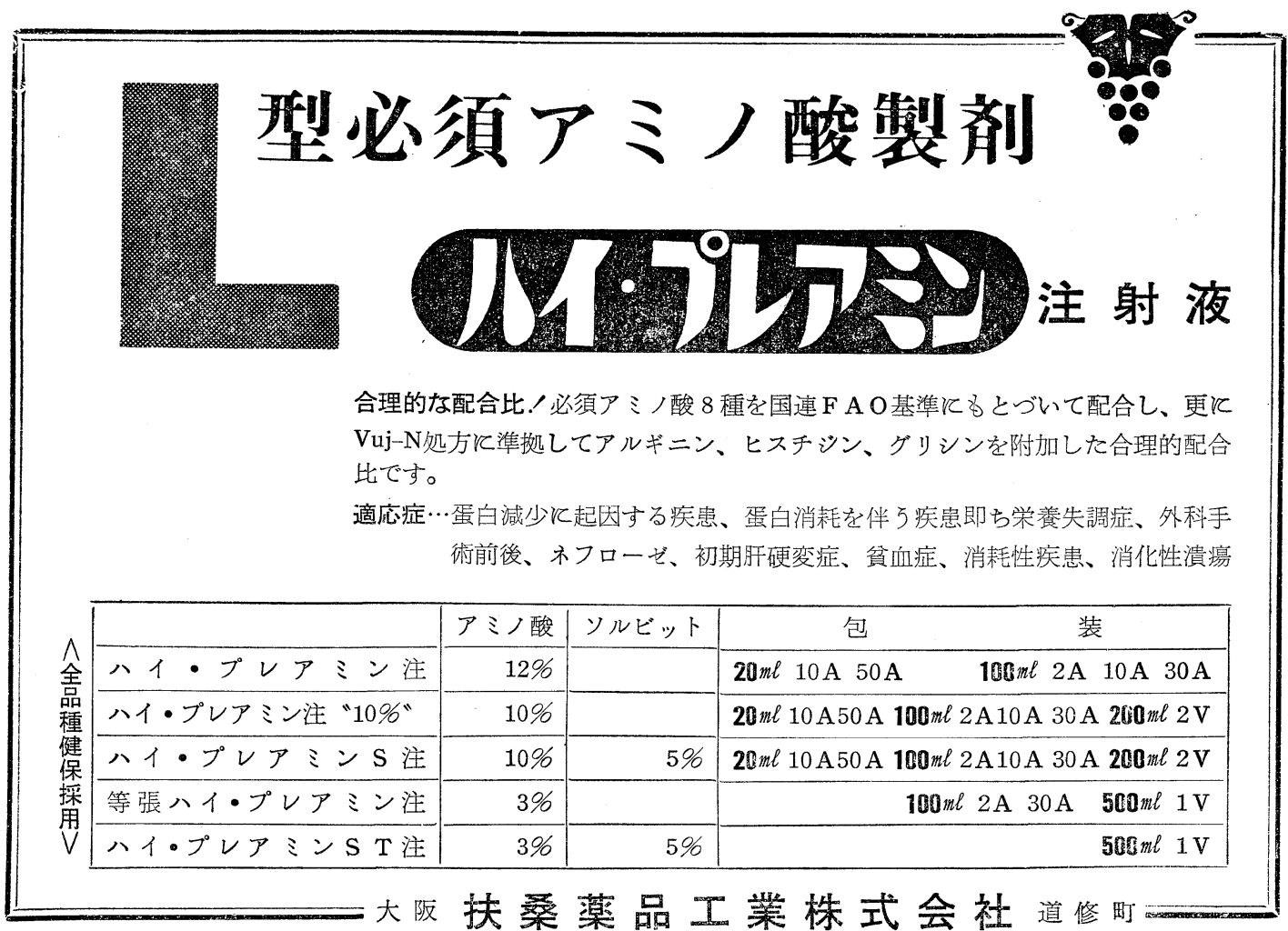




\section{III. 科学展示抄録}

眼科領域のリハビリテーション

（東京大学眼科）原田 政美 医学的抹よび社会的リハビリテーションのために用い られる各種の器械拉よび物品を展示した (写真参照)。

1. 斜視および弱視訓練器械

(1) シノプトフォア：写真の右端にある大きな器械 で，斜視の両眠視訓練と弱視の訓練。

(2) ムネモスコープ: 写真の左端にある器械で, プロ ジェクターで投影した図形の記憶を利用する弱視の視知 覚訓練。

（8）コオルヂナトール：視線の中心だけで認識できる ハイジンガーのブラッシュを：偏光板を回転することに より認め易くした器械, 弱視の中心固視確立訓練。

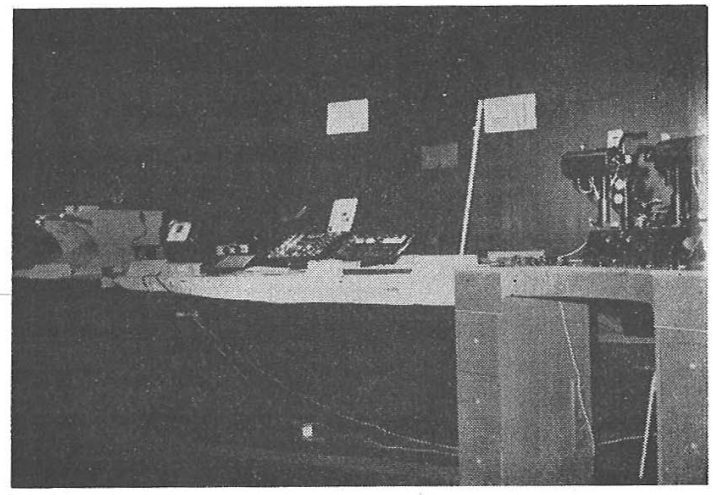

(4) オイチスコープ: 残像を利用した弱視訓練。

(4) カイロスコープ : 斜視の両眼視訓練。

2. 弱視レンズセット

各種の型特よび倍率を持った拡大レンズを収容したも ので，弱視者の読書能力などを向上させる。

3. コンタクトレンズ

コンタタトレンズの製作工程説明図と, 試験レンズセ ット。

\section{4. 盲人用の補装具その他}

(1) 杖: 折りたたみ用。

（2）地図 : 表面々凸凹があり点字で地名記入。

(3) 算盤：角形の珠を上方《倒す。

(4) 点字板抒よび点字印刷物。

（5）将棋和よびトランプ：触覚が利用できるようK工 夫されたもの。

(6) 物指・分度器・針の目通乙：同上。

\section{5. 弱視学級用教科書}

盲学校内弱視学級用教科書として文部省が編集したも ので，1年から6年用までがある。

\section{IV. 映画展示抄録 [1] [ 6$]$}

[1]車椅子の社会人たち

一一東京パラリンピック印象記——

（東北労災病院整形外科）木村 元吉

この映画山1964年11月，東京で開催されたパラリンピ ックの印象記である。したがって，競技の種類ならびル その記録をレンズを通して紹介したものでなく，むしろ それは最小限に止めた。結論的にいうならば，その印象 は，外国の選手は車椅子《乗った社会人であり，日本の 選手恃車椅子飞乗った病人ということであって，両者の 違いそれ自身が，リハビリテーション体系の整備ないし その内容とそれと表裹一体である人間尊重の理念の優劣 有無を表わしているというととである。かかる観点から この映画製作された。

○規格 $8 \mathrm{~mm}$, トーキー，50分

〔2】脊髄損傷および半身不随患者の戸外リハビリテ ーション

（堺市耳原病院整形外科）馬場 三郎

目的; 春髄損傷㐨よび脳卒中により半身不髄となった 患者で自力にて起立できる程度以上に回復したものに対 して戸外でリハビリテーションを行ない，人生を半ば諦 め加けている不幸な患者の将来湖るい希望を与兄る一 つの試みとして行なわれた。

症例

1. 51歳工員男子。第一腰椎脱臼骨折による下肢の対 麻㾖 (不全麻痺) 手術例

2. 26歳船員男子, 第一腰椎脱臼骨折飞よる下肢の対 麻瘦 (完全麻瘦)

3. 22 歳主婦，下部胸髄部の血管腫とよる下肢の対麻 㿎手術例

4. 53歳男子。右半身運動麻㾝兼左肘関節陳旧性脱曰 括よび動脈硬化性心不全

本例々 7 年閒病床にあり人生を全く棓めていたが右下 腿の高度皮膚炎による部分的壊死のために切断をすす られて来院した悲惨な症例であったが, 入院後 3 力月起 立が可能となった。

成果 ; 戸外リハビリテーションを転機として特と症例 3 は精神的飞著しく成長し, 又症例 4 は時間をかけて 10 米位補助歩行が可能となった。
○規 格……8 $\mathrm{mm}$
○映写時間………15分
○テープレコーダー解説 


\section{[3] C.P. の更生指導と就労の実態}

（広島脳性麻痺研究グループ）佐藤 俊之 広島県飞和ける脳性麻盘の療育ならぴに職業指導につ いて，各施設現状の瞥見呿よび実社会に捛けるC.P. 者 就労の実態を記録したものである。

16ミリ，カラー, 16コマ

○映写時間……25分

\section{[4]進行性筋ヂストロフィーのリハビリテーション} (德島大学整形外科学教室)

野島元雄 新野 徳 岩城 孝 山本博司 会員講演[15]進行性筋ヂストロフィーのリハビリテイ ション（野島他）〔16]進行性筋ヂストロフィーに対する. 補装具バネ附き下肢装具並びに肩甲骨固定装置飞ついて （有田他）の講演内容を映画により詳細に紹介した。

\section{〔5〕日本における下肢切断者の諸問題}

(神戸大学整形外科教室) 沢村誠志 宇野衛男

吾々は，下肢切断者のリハビリテーションについて検 討してきたが，日本て抒いては，他の諸外国と生活様式 その他で種々の特種な条件があり，義肢の処方その他に 特別な考慮が不可欠である。今回は, 最近数カ年にわた り装具訓練を行って社会復帰せしめた症例，和よび，巡 回診療に和いて義肢の使用状況を観察しえた症例を中心 にして，これらの問題を検討したので，映画により供覧 する。

尚，吾々の下肢切断者に対する義足の処方方針は，股 離断者には, カナダ式を, 大腿切断者では適态可能者す べてに吸着式，膝接手遊動を，不適応者には常用を，膝 関節離断者には，吸着義足または，2 重合成樹脂製ソケ ットを, 下腿切断者には, 原則として膝蓋腱荷重下腿義 足（PTB）を処方した。これらの装着訓練の方法なら びに効果, 実用的な歩行能力については, 第37回日整会 総会で発表した通りである。

次に, 問題点を列挙すると,

1）日本式家屋では，履物の着脱による踵の高さ変化 そよるアラインメイント変化が抗こる。畳の上での歩行 では，ある程度とのクッションによるため歩行能力に影 響が少なく，特に，一側下腿切断者では，足先歩行によ り支障をみとめる場合浪えどないが，両側下肢切断者 では, 後方に倒れる感じがあり, 安定性に充分注意を必 要とし, 踵の高い履物に合わせて, アライメントを設定 する事に注意を必要とする。

2）履物は，着脱に容易なものと同時に，下駄，草履 をはく女性の場合，地下足袋をはく労働者では，義足前 足部のわれたものの処方が必要である。尚，一方，農業
従事者では，地形の関係上，また，水田での農耕上，前 足部をかき，足接手の腐蝕を防ぐため Dollinger 型義 足の処方の必要性をみ々めるの従来通りである。

3）ついで，問題となるのは，屋内での坐位の問題で ある。一応，現状では，男性の場合には胡坐のとりうる 事，女性の場合には，横坐りが可能かどうかを目標にす べきであろう。しかしながら，カナダ式股義足装着例で は，股接手の機構上，横坐りは不能であり，必ず，前に 足を投げ出して坐位をとることが要求される。大腿切断 者，吸着義足装着例では，適合がソケットの緊張度の強 い場合飞，足部の回旋を制限するため，胡坐，横坐りほ 不能であり，筋肉の収縮による義足保持の可能な例で は，解剖学的適合飞注意して，緊張度を比較的少なくす れば，胡坐，横坐りは可能となる，尚，僧侶，師匠等の 日本固有の職業をもつ切断者の場合には，足部の回旋を 容易ならしめるため膝上部にターンテーブルを処方して いる。

下腿切断者の場合，いわゆる常用下腿義足装着者では 比較的問題が少ないと思われるが，最近，吾々が好んで 用い，優性秀を認めているP T B下腿義足でね，ある程 度の滕屈曲制限という問題が残されている。特に，滕屈 曲位でのアライメントの設定, 解剖学的適合を重要視 し，とくに，後壁の高さを相当㛜密に行なう必要があ る。また, 膝屈曲位歩行飞対するベルトの緊張性の重要 な事も膝屈曲制限の一因となっている。従って，現在で のこの型の義足の処方は, 職業, 性等により注意を要 し，同時に，この面での改良が望まれる。

4) 日本式トイレの問題, 膝接手屈曲, 足接手背屈が 加わるため，重度の下肢障害者には大きな問題である。 一側下腿または大腿切断, 一側下眼他側大腿切断例では 比較的問題とならぬが，両側大腿切断側では，安定性の 保持，吸着の保持を失わ様に，殆ど立位で，股関節を 屈曲位をとり行うか，両下股を前に投げ出して坐りこむ か，また，特別な椅子を作裂し，坐る様にすることが重 要である。

5）実用的な歩行能力について，

すでに，義肢歩行能力について吾々の報告したごと く, 日本での道路条件, 通勤通学の状態等を考慮しなけ れば，リハビリテーションの方向づけを謓まることがあ る。とくに, 農村, 漁村での生活で, 義肢の安定性を必 要とする場合が殆どで, 特に, 股義足和よび大腿義足で 滕遊動の処方を行っても実用的な滕固定を望むことが少 なくない。又，都会での通勤通学のラッシュ時の，階段 歩，乗行物の選択等が，切断者にとり苦悩の一つであ り，現在吾々の行っている義肢装着訓練方法も難路歩行 能力を最終目的として拈り，将来の方向として切断者の 
自動車訓練を併用すべきであると感じている。

\section{[6] 脳卒中のリハビリテーション}

(16mm, カラー, 光学録音, 15 分45秒)

(大阪大学整形外科) 水野祥太郎

脳卒中後の片麻疩患者にみられるいろいろの特徵, す
なわち，屈曲同調・伸展同調運動，分離協同動作の困難 性, 知覚異常の状態を示し, つぎに, 発作直後の bed exercise から，坐位起立訓練，運動発達様式飞従う訓 練方法を示した。

上肢機能については, とくと職能療法を用いた訓練方 法を示した。

\section{《投 稿，掲 載 規 定》}

日本リハビリテーション医学会会員よりの投稿を歓迎します。

つぎの投稿規定を厳格にまもつてください。

\section{○投稿について}

（1）編集委員会が寄稿它依頼した綜説・展望・技術解説などは希望枚数以内にまとめて下さい。原著は 400 字詰原稿用紙 20 枚，眓表 5 枚以内は無料で揭載し，規定を超過した場合には超過分に要した一切 の実費をいただきます。原著以外の投稿な予め編集委員に連絡し，枚数の指定を受けてください。

（2）原稿は平がな，口語文，現代かなづかいとし，外国文字はタイプするか丈は印刷体で明瞭に記入のこ と。

（3）原稿には欧文の題名・所属・氏名をつけてください。

(4) 原著には 400 語以内の欧文抄録および邦訳をかならずつけてください。

（5）度量衡は $\mathrm{mm}, \mathrm{cm}, \mathrm{m}, \mathrm{m} l, l, \mu \mathrm{g}, \mathrm{g}, \mathrm{C}, \mathrm{mEq}$ などとする。慣例上 CGS 単位以外を使用する場合 には括弧内に CGS 単位に換算した数值を記入すること。

（6）図表は必要の限度内に止め，同一事項について両者が重複せぬよう御注意ください。誌面の一面に入 り得ない膨大な表は組めません。

（7）引用文献は少なくとも次の事項を明らかにして下さい。 雑誌の場合一一著者名：誌名, 巻, 頁, 発行年 (西暦)

例勝沼晴雄・他：日本公衛誌，10，95，1963.

Ward, L. E. : Arth. \& Rheum., 6, 650, 1963.

単行本の場合——著者名：書名 (必要あれば引用頁), 版数, 発行所, 発行年

例 Daniels, L. et. al : Muscle Testing, 2nd ed., W.B. Saunders, Philadelphia, 1959.

（8）著者校正は原則として1回とし，校正は赤インクでお願いします。校正の方法の詳細は医学書院 PR 課にお申し出になれば「執筆・校正のしおり」をお送りいたします。

\section{○揭載について}

（1）寄稿論文の採否は編集委員会で決定し，多少の字句の訂正もすることがあります。なお，掲載予定の 原稿であつても投稿規定に反する場合には一部の変更をお願いすることがあります。

（2）別刷は50部を無料で，それを超える分については著者の希望により実費でさしあげます。

\section{O原稿送付先}

東京都文京区雑司谷

東京大学医学部付属病院分院内

日本リハビリテーション医学会 宛 